\title{
Exploring phylogeny of the microsoroid ferns (Polypodiaceae) based on six plastid DNA markers
}

\section{Chen, Chi-Chuan}

2020-02

Chen , C-C , Hyvönen , J \& Schneider , H 2020 , ' Exploring phylogeny of the microsoroid ferns (Polypodiaceae) based on six plastid DNA markers ', Molecular Phylogenetics and Evolution , vol. 143 , 106665 . https://doi.org/10.1016/j.ympev.2019.106665

http://hdl.handle.net/10138/321115

https://doi.org/10.1016/j.ympev.2019.106665

cc_by_nc_nd

acceptedVersion

Downloaded from Helda, University of Helsinki institutional repository.

This is an electronic reprint of the original article.

This reprint may differ from the original in pagination and typographic detail.

Please cite the original version. 


\section{Journal Pre-proofs}

Exploring phylogeny of the microsoroid ferns (Polypodiaceae) based on six plastid DNA markers

Chi-Chuan Chen, Jaakko Hyvönen, Harald Schneider

PII:

S1055-7903(19)30390-2

DOI:

https://doi.org/10.1016/j.ympev.2019.106665

Reference:

YMPEV 106665

To appear in:

Molecular Phylogenetics and Evolution

Received Date: $\quad 27$ June 2019

Revised Date: $\quad 25$ October 2019

Please cite this article as: Chen, C-C., Hyvönen, J., Schneider, H., Exploring phylogeny of the microsoroid ferns (Polypodiaceae) based on six plastid DNA markers, Molecular Phylogenetics and Evolution (2019), doi: https:// doi.org/10.1016/j.ympev.2019.106665

This is a PDF file of an article that has undergone enhancements after acceptance, such as the addition of a cover page and metadata, and formatting for readability, but it is not yet the definitive version of record. This version will undergo additional copyediting, typesetting and review before it is published in its final form, but we are providing this version to give early visibility of the article. Please note that, during the production process, errors may be discovered which could affect the content, and all legal disclaimers that apply to the journal pertain. 


\section{Cover Page}

Exploring phylogeny of the microsoroid ferns (Polypodiaceae) based on six plastid DNA markers

Corresponding author :

Full name: Harald Schneider

Mail address: Center for Integrative Conservation, Xishuangbanna Tropical Botanical Garden; Chinese Academy of Sciences; Mengla, Yunnan 666303; China

E-mail address: $\underline{\text { harald@xtbg.ac.cn }}$

Number of tables: 5

Number of black-and-white figures: 5

Declarations of interest: none 


\title{
Exploring phylogeny of the microsoroid ferns (Polypodiaceae) based on six plastid DNA markers
}

\author{
Chi-Chuan Chen ${ }^{1,2}$, Jaakko Hyvönen ${ }^{1}$, and Harald Schneider, ${ }^{2, *}$ \\ ${ }^{1}$ Organismal \& Evolutionary Biology, Viikki Plant Science Center \& Finnish Museum \\ of Natural History (Botany), PO Box 7, FI-00014 University of Helsinki, Finland; \\ ${ }^{2}$ Center for Integrative Conservation, Xishuangbanna Tropical Botanical Garden;
} Chinese Academy of Sciences; Mengla, Yunnan 666303; China;

*Corresponding author; e-mail: harald@xtbg.ac.cn

\section{ABSTRACT:}

The microsoroid ferns are one of the largest subfamilies of the Polypodiaceae with over 180 species mainly found in the humid forests of tropical Australasia. The phylogenetic relationships are still unclear, especially the delimitation of the genus Microsorum which has been recognized to be non-monophyletic. We analysed the microsoroid ferns using six chloroplast DNA regions ( $r b c L, r p s 4+r p s 4-t r n S$, $\operatorname{trn} L+\operatorname{trn} L-\operatorname{trn} F, a t p A, a t p B$ and $m a t K)$ in order to present a robust hypothesis of their phylogeny. Our results suggest that they comprise up to 17 genera; of them, 12 agree with a previously accepted generic classification. Five tribes are proposed based on the phylogenetic relationships. Most of the species traditionally included in the genus Microsorum are found in six genera belonging to two tribes. In addition to the commonly used DNA markers, the additional atpA and mat $K$ are helpful to provide information about the phylogenetic relationships of the microsoroid ferns.

\section{KEYWORDS:}

microsoroid ferns; phylogeny; Polypodiaceae; matK; atpA 


\section{INTRODUCTION}

The microsoroid ferns is the third largest out of the six subfamilies of Polypodiaceae containing ca. 12 genera and over 180 species (PPG I, 2016). The lineage is widely distributed in the tropical and subtropical regions of the Old World and Oceania with the range reaching from Japan to Australia and New Zealand, and from Africa, Madagascar, through South and Southeast Asia to South Pacific islands. The microsoroid ferns can be found in terrestrial, epipetric, and rheophytic habitats, as well as growing as epiphytes. The majority of species are usually found in forests with high precipitation, or in habitats close to the water.

There are different opinions regarding the taxonomy of the microsoroid ferns since the morphological similarity and disparity do not reflect well the delimitation (e.g.

Hetterscheid \& Hennipman, 1984; Bosman, 1991; Nooteboom, 1997). Various authors have proposed several related genera within the microsoroid ferns based on the morphological differences (Table 4). However, with later studies incorporating molecular data, many of these genera were subsequently merged (Wang et al., 2010b; Kim et al., 2013; Wei et al, 2017). The latest classification PPG I (2016) accepted 12 genera within the microsoroid ferns treated as a subfamily. In addition to Microsorum Link, Goniophlebium (Blume) C. Presl, Lecanopteris Reinw. ex Blume, Lemmaphyllum C. Presl, Lepidomicrosorium Ching \& K.H.Shing, Lepisorus (J.Sm.) Ching, Leptochilus Kaulf., Neocheiropteris H. Christ, Neolepisorus Ching, Paragramma (Blume) T. Moore, Thylacopteris Kunze ex J. Sm., and Tricholepidium Ching are currently accepted. However, the previous studies also pointed out that Microsorum s.l. is a paraphyletic unit that requires further attention. (e.g. Kreier et al., 2008; PPG I, 2016).

Various classifications have been presented above the generic level. Hennipman et al. (1990) suggested two subfamilies and six tribes within Polypodiaceae, the microsoroid ferns being tribe Microsoreae containing eight genera, Christiopteris Copel., Dictymia J. Smith, Colysis C. Presl, Lecanopteris, Leptochilus, Microsorum, Neocheiropteris, and Phymatosorus Pic.Serm. The morphological characters of this tribe include leaves that are simple or variously dissected, leaf indument such as scales and/or hairs, spore exospore usually thin and perispore is variable, as well as stem scales usually clathrate. Among these eight genera, the last six are accepted as the microsoroid ferns in the latest classification PPG I with Colysis included within Leptochilus, but the Australian species of Colysis have been placed in another clade (Testo \& Sundue, 2014).

Christiopteris and Dictymia have been placed in the subfamilies Drynarioideae and Loxogrammoideae, respectively (PPG I, 2016). The subdivision of Hennipman et al. (1990) provides a preliminary classification of the microsoroid ferns, but is still treated as provisional and likely artificial (Schneider et al., 2004b). 
With the studies based on DNA sequences during the past decade, the phylogenetic relationships of the microsoroid ferns have also been assessed not only locally (Schneider et al., 2004a, 2006; Kim et al., 2013), but also on a global scale (Schneider et al., 2004b; Kreier et al., 2008; Nitta et al., 2018). Based on plastid DNA markers, the microsoroid ferns appear to be monophyletic, but some traditional genera such as Microsorum and Phymatosorus were found to be paraphyletic or polyphyletic (Bosman, 1991; Schneider et al., 2004b; Kreier et al., 2008; PPG I, 2016). The deeper relationships of the microsoroid ferns including tribes Microsoreae, Polypodieae, and Lepisoreae as presented by Hennipman et al. (1990) were studied by Kreier et al. (2008) using four chloroplast regions ( $r b c L, r p s 4$, rps4-trnS IGS, and trnL-trnF IGS) from 107 samples of 87 species. Six groups were described: membranaceoid, lecanopteroid, lepisoroid, microsoroid s.s., thylacoperoid, and goniophlebioid clades, with the first four clades belonging to the core microsoroids. Some of the clades were subsequently studied more to clarify the classification, such as the lepisoroid clade (Wang et al., 2010a, 2010b) following the tribal ranking of Hennipman et al. (1990), Leptochilus which is part of the microsoroid s.s. clade (Zhang et al., 2019), and in light of the recent study lecanopteroid ferns (Testo et al., 2019). One of the reasons for morphological similarity between species of the microsoroid ferns is hybridization, with many hybrid species reported (Nooteboom, 1997; Fraser-Jenkins, 2008; Nitta et al., 2018; Zhang et al., 2019), especially within the microsoroid s.s. clade of Kreier et al. (2008). This makes generic delimitation difficult in some cases (Nitta et al., 2018). There are still many relationships to be solved within the microsoroid ferns although the main groups have been delimited (Kreier et al., 2008; Nitta et al., 2018). In this study, we assembled a comprehensive taxon sampling from all 12 genera as defined in PPG I (2016), with six sampled chloroplast regions. Of them, markers matK and atpA are used for the first time in phylogenetic analysis of this group. We aimed to reevaluate the phylogeny with a focus on higher ranks, in order to provide a robust classification of this fern group.

\section{MATERIAL AND METHODS}

\section{Taxon sampling}

The taxa were sampled (Table 1) to capture a wide range of variation of microsoroid diversity, containing the type species of all previously proposed genera whenever possible (Table 4). The circumscriptions of the genera used in this study mainly follow PPG I (2016) with 12 genera accepted, including Lepidomicrosorium, Leptochilus, Microsorum, Neocheiropteris, Neolepisorus, Thylacopteris, Goniophlebium, Lecanopteris, Lemmaphyllum, Lepisorus, Tricholepidium, and Paragramma. Of these, the sequences for the first six genera were mainly generated in this study, while the 
sequences of the last six were mostly from previous studies and thus downloaded from GenBank. In total, 316 terminals were included representing 155 species (Table 1). The species Aglaomorpha meyeniana Schott, Polypodium glycyrrhiza D.C. Eaton, and Pyrrosia polydactyla (Hance) Ching were chosen as outgroup terminals based on their close relationship with the microsoroid ferns (PPG I, 2016).

Material for generating DNA sequences were collected from the wild, herbarium specimens, or from plants cultivated either in the Xishuangbanna Tropical Botanical Garden (XTBG) or the Koo Botanic Conservation Center (KBCC). Voucher specimens of the newly collected specimens were deposited in the herbarium (HITBC) of Xishuangbanna Tropical Botanical Garden of Chinese Academy of Sciences, and the Botanical Museum of the University of Helsinki (H). Altogether 438 novel sequences were generated in this study.

\section{Extraction, amplification, and sequencing}

For each sample, genomic DNA was extracted from ca. $20 \mathrm{mg}$ of silica-dried leaves by using EasyPure ${ }^{\circledR}$ Plant Genomic DNA Kit (Beijing, China). The extracts were used directly for PCR amplification with the various primers (Table 2). The PCR reactions were performed in a $50 \mu$ volume containing $>20$ ng genomic DNA, $5 \mu$ 10x EasyTaq buffer, $4 \mu \mathrm{dNTP}$ solution $(2.5 \mathrm{mM}), 1 \mu \mathrm{l}$ of each primer $(10 \mu \mathrm{M})$, and $0.5 \mu \mathrm{l}$ EasyTaq DNA Polymerase. We chose six DNA regions to be used: rbcL, rps4+rps4-trnS (rps4 gene and rps4-trnS intergenic spacer), $\operatorname{trn} L+\operatorname{trn} L-\operatorname{trn} F$ ( $\operatorname{trn} L$ intron and trnL-trnF intergenic spacer), atpB, atpA and $m a t K$. The three regions listed first were used in the earlier studies (e.g. Schneider et al., 2004b, 2006; Kreier et al., 2008; Wang et al., 2011). Also $a t p B$ and $r b c L-a t p B$ have been used previously (Wang et al., 2010a, 2010b; Kim et al., 2013; Wei et al., 2017; Zhang et al., 2019). The latter two, atpA and matK, were used for the first time for the microsoroid ferns in this study. The matK region was amplified using primers designed for the CBoL plant Barcode (see CBoL Plant Barcoding Group 2009; http://api.ning.com/files/BUlqLWUg9ErBrrLy0nYWDNOINjg*fmvyMzVAb4L6oMW usIlOs1eJWVNkti4LNRtUgt3IVmhw9YnTKOZhG8EyUeoYpXRWp1xc/Fern_matK_ RBGE_PROTOCOLv1.0.pdf).

\section{Sequence alignment and phylogenetic analysis}

The DNA strands were assembled and edited using BioEdit (Hall, 1999) and aligned using MUSCLE (Edgar, 2004) within Mesquite 3.31 (Maddison \& Maddison, 2017). The obtained alignments were checked visually for ambiguously aligned regions that were subsequently excluded. In addition, the sequences of $r b c L$-atpB from GenBank were merged with $a t p B$ since it was available for most of the taxa, especially Lepisorus, 
Lemmaphyllum, and Lepidomicrosorium. In total, we obtained 308 sequences for $r b c L$, 310 for rps $4+r p s 4-t r n S, 302$ for $t r n L+t r n L-t r n F$ regions, 185 for $r b c L-a t p B+a t p B$, 62 for $a t p A$, and 51 for $m a t K$. The novel sequences were deposited in GenBank (see Table 1 for accession numbers).

We compiled four concatenated datasets, three of them were large containing all 316 taxa but the combined DNA regions differed: 1) concatenated dataset of all six DNA regions of 316 samples, with atpA and matK regions lacking for most of the terminals; 2) concatenated dataset of four DNA regions ( $r b c L, r p s 4+r p s 4-t r n S$, trnL+trnL-trnF, and $r b c L-a t p B+a t p B)$, with $r b c L-a t p B+a t p B$ available only for part of the terminals; and 3 ) concatenated dataset of three regions ( $r b c L, r p s 4+r p s 4-t r n S$, and $\operatorname{trn} L+\operatorname{trn} L-t r n F)$ with relatively complete representation of all the terminals. These three combinations of large datasets were analysed to assess whether and how much different number of terminals and available sequences affect obtained topologies. The fourth concatenated dataset was small and designed to further check the obtained phylogenetic structure. It contained 50 taxa representing all 12 genera, with data of all six regions.

Maximum Likelihood analyses (ML) were performed using IQ-Tree 1.5.6 (Nguyen et al., 2015), and Bayesian Inference (BI) using MrBayes v. 3.2.6 (Ronquist and Huelsebeck, 2003). The partitionFinder (Lanfear et al., 2016) was used for both ML and BI analyses. For ML, ModelFinder (Kalyaanamoorthy et al., 2017) was used to identify the best fitting model for these analyses which was implemented in IQ-Tree 1.5.6. (Nguyen et al., 2015). Bayesian Information Criterion (BIC) was selected for all datasets, and the best fitting models was found for each DNA region separately (Table 3). ML analyses were run simultaneously under default settings with both non-parametric bootstrap analyses using the ultrafast bootstrap (UFBoot; Minh et al., 2013), Shimodaira-Hasegawa-like approximate likelihood ratio test (SH-aLRT;

Guindon et al., 2010), and the Bayesian-like transformation of aLRT (aBayes; Anisimova et al., 2011) as implemented in IQ-Tree (Trifinopoulos et al., 2016). The interpretation of the support values employed the criteria following previous publications (e.g. Minh et al., 2013).

For the BI analyses, not only partitioned regions but also the best fitting models were selected using partitionFinder (Lanfear et al., 2016). Markov chain Monte Carlo was run independently twice with one cold and three hot chains. In each run, chains were sampled every 1000 cycles. A total of 10,000,000 generations were run and a majority rule consensus tree was calculated based on all trees sampled except that the first $25 \%$ of the sampled trees were discarded within the burn-in phase, which was examined using Tracer v. 1.6 (Rambaut and Drummond, 2007) to ensure convergence of chains and sufficient sampling of generations. The posterior probabilities (PP) were calculated 
and presented using the majority rule consensus tree. The published results were based on the concatenated datasets including all regions using the partitioning (Fig. 1, 2).

We performed an analysis of the largest dataset with parsimony as an optimality criterion using the program TNT (Goloboff et al., 2008; Goloboff and Catalano, 2016) that provides efficient algorithms for the analyses of large (> 200 taxa) datasets. By including in the analyses also the specimens with only part of the sequences, we wished to see how they affected the results obtained. The pathological behavior of specimens with only part of the characters (Wheeler, 2012) is well known (e.g. Nixon and Davis, 1991; Platnick et al., 1991) but results of several studies (e.g. Lehtonen, 2011; Wolsan and Sato, 2010) suggest that analyses of even sparse matrices are worthwhile. Analyses using TNT were performed with the search settings following the settings used in Wheeler et al. (2017). Initially, parsimony uninformative characters were removed from the matrix using "mop uninformative characters" function of the program Winclada (Nixon, 2002). This resulted in a matrix of 316 terminals and 2184 characters. Searches were initiated with ten replicates of RAS (random addition sequence) + TBR (tree-bisection-reconnection) branch swapping, and this was performed 30 times in order to get a large pool of diverse trees that were already closer to an optimal solution, rather than a sample of random trees. After this, each set of 10-30 trees (trees saved per replicate 1, 2, or 3) obtained were subjected to a new technology search composed of sectorial search (random and mixed sectorial searches) plus tree-drifting (Goloboff, 1999), with default settings. Finally, all trees were combined and subjected to 1000 rounds of tree-fusing (Goloboff, 1999), again using default settings of the program.

\section{RESULTS}

The tree topologies resulting from analyses of the three large datasets were generally congruent. In all the topologies, Thylacoptereae then Goniophlebieae were successively sister to the core microsoroid ferns which was in turn comprised of Lecanoptereae, Microsoreae, and Lepisoreae (Figs. 1, 2, 4). The Microsoreae and Lepisoreae were sister clades to which the Lecanoptereae was a sister (Figs. 1, 4). The Lecanoptereae (Fig. 1) contained the ant-fern genus Lecanopteris and three lineages comprising species of Microsorum; two of them, groups MG2 and MG3, contained mostly Australasian species. These two groups plus Lecanopteris formed a branch with high bootstrap and posterior values (Fig. 1; aLRT $=100 \% /$ aBayes $=1.00$ / UFBoot $=100 \%$ / PP = 1.00). Together, they were sister of MG1.

Microsoreae and Lepisoreae clades comprised the majority of the microsoroid ferns. Of them, Microsoreae consisted of four clades, Leptochilus, core Microsorum, MG4, and MG5; the majority of the sampled Microsorum species were placed in the latter 
three clades. The clades MG5 and Leptochilus were sister to each other (Fig. 1; aLRT = $99.5 \% /$ aBayes $=1.00 /$ UFBoot $=100 \% / \mathrm{PP}=1.00)$ and together were a sister clade of the clades MG4 and core Microsorum (Fig. 1; aLRT $=89.9 \% /$ aBayes $=1.00 /$ UFBoot $=99.0 \% / \mathrm{PP}=1.00)$. The type species of Microsorum $(M$. punctatum $(\mathrm{L})$. Copel.) and Phymatosorus (M. scolopendria (Burm. f.) Copel.) were nested in the core Microsorum but in different subclades (Fig. 1; Table 4).

There were seven genera in the tribe Lepisoreae and it was divided into three main clades. Lepisorus and Paragramma were two clades with the rest five genera, Neolepisorus, Lemmaphyllum, Tricholepidium, Neocheiropteris, and Lepidomicrosorium forming one clade (Fig. 2). Among these Lemmaphyllum was separated from the other four genera (Fig. 2; aLRT $=100 \% /$ aBayes $=1.00 /$ UFBoot $=$ $100 \%$ / PP = 1.00). Neolepisorus, Tricholepidium, Neocheiropteris, and Lepidomicrosorium were monophyletic, with the first one as a sister of the other three. The position of Paragramma longifolius (Blume) T. Moore and Lepisorus accedens (Blume) Hosok differed among the tree topologies that resulted from the three large datasets. Paragramma was sister of Lepisorus in the analysis based on four gene regions, or placed as a first branch within Lepisoreae, which was sister of the other six genera in the analyses based on three and six genes regions (Figs. 1, 4). Lepisorus accedens was sister to Lemmaphyllum in the analysis of three genes (Fig. 4), whereas it was nested within Lepisorus in both of the four and six gene region analyses (Figs. 1, 4).

A similar topology was also found in the ML analysis of the small dataset which included $P$. longifolius but without $L$. accedens (Fig. 3). The tribe Lepisoreae was a clade with high support value both in large (Fig. 2; aLRT $=100 \% /$ aBayes $=1.00$ / UFBoot $=100 \% / \mathrm{PP}=1.00$ ) and small (Fig. 3; aLRT $=99.9 \% /$ aBayes $=1.00 /$ UFBoot $=100 \%$ ) dataset analyses, but the node after $P$. longifolius had lower support values in both large and small dataset (Fig. 2; aLRT $=61.9 \% /$ aBayes $=0.953 /$ UFBoot $=93 \% / \mathrm{PP}=0.997$; and Fig. 3 ; aLRT $=68.2 \% /$ aBayes $=0.98 /$ UFBoot $=$ $79 \%$ ). The parsimony analysis based on six genes resulted in a similar topology, but the position of L. accedens was unresolved; it was a branch of the large polytomy of the Lepisoreae (Fig. 5). The tree is consensus of 1714 equally parsimonious trees with a length of 7677 steps. As can be seen the number of trees was inflated mostly by the conflict in some smaller groups.

\section{DISCUSSION}

Our results reveal that the microsoroid ferns can be divided into 17 clades, with aLRT $>97 \%$, aBayes $=1$, UFBoot $\geq 99 \%$, and $\mathrm{PP}=1 ;$ and 12 of these clades are accepted in the generic classification of PPG I (2016). Our results agree with previous studies that 
supported traditional Microsorum and Phymatosorus as being not monophyletic. These species can be found in several clades containing MG1-MG5 plus core Microsorum, and thus the delimitation of these genera needs to be reevaluated. In addition, there are five tribes within the microsoroid ferns that are recognized in this study.

\section{The use of $\operatorname{atp} A$ and $m a t K$ in the phylogenetic analyses of the microsoroid ferns}

We analysed three large datasets included different numbers of DNA regions (three, four, and six). Of them, the one with three included the DNA regions $r b c L, r p s 4+$ rps4-trnS, and trnL+trnL-trnF that have been used in previous phylogenetic studies of microsoroid ferns (e.g. Kreier et al., 2008). The one with four regions also include $r b c L-a t p B+a t p B$ besides those listed above. This region was used previously to study the phylogenetic relationships of Lepisorus species (Wang et al., 2010a). The regions $a t p A$ and $m a t K$ have been considered to be useful markers for solving the core relationships of ferns (Schuettpelz et al. 2006; Kuo et al., 2011). Although these two regions were obtained only for small proportion of our samples they were added to the largest dataset.

The trees inferred from the three large concatenated datasets show relatively consistent results, in that there are 17 main groups in all trees, but clades are supported differently among the datasets, especially for the relationships of the core Microsorum and MG4. The clades containing these two groups are weakly supported in the three- combination dataset (Fig. 4; aLRT $=51.4 \% /$ aBayes $=0.93 /$ UFBoot $=87.0 \%)$, but are better supported in the four-combination (Fig. 4 ; aLRT $=72.1 \% /$ aBayes $=0.99 /$ UFBoot $=$ 97.0\%) and six-combination datasets (Fig. 4; aLRT $=89.9 \% /$ aBayes $=1 /$ UFBoot $=$ 99.0\%). These results agree that atpA and matK improve the resolution of the phylogenetic framework of the microsoroid ferns. Unfortunately, the relationships within Lepisoreae did not improve much among three datasets. This was likely caused by the limited number of sampled species, since most of the atpA and matK data are from Microsoreae species and only a few are from tribe Lepisoreae (Table 1).

\section{Phylogenetic relationships and the delimitation of tribes of the microsoroid ferns}

Our phylogenetic trees are composed of five well-supported branches (Fig. 1 \& 2; Fig. 3 ), and this is congruent with the results obtained in the previous studies (Kreier et al., 2008). In order to make taxonomy useful, suitable ranks within the microsoroid ferns are needed, since it is such a large and diverse fern group. We follow PPG I (2016) that uses subfamily rank for the monophyletic microsoroid ferns; and the following five main branches are given the tribe rank here: Thylacoptereae, Goniophlebieae, Lecanoptereae, Microsoreae, and Lepisoreae. These proposed tribes differ from their earlier definition (Hennipman et al., 1990), since not only morphology but also 
molecular data have now been used. This framework reveals our current understanding about the relationships of the microsoroid ferns. The delimitation of the proposed tribes is almost identical with the clades used by Kreier et al. (2008) except for the tribe Lecanoptereae, which contains both Lecanopteroid and Membranaceoid clades (Kreier et al., 2008).

Tribe Thylacoptereae C.C. Chen \& H. Schneider, trib. nov. —TYPE: Thylacopteris Kunze ex J. Smith

Only one genus Thylacopteris and one species T. papillosa was included in this study. Thylacopteris is a small genus with only two species. The distinguishing characters of this genus include free venation, the articulation of the lateral segments with the rhachis, and jigsaw-puzzle-shaped rhizome scales with a warty inner thickened layer. (Rödl-Linder, 1994).

Tribe Goniophlebieae C.C. Chen \& H. Schneider, trib. nov. - TYPE: Goniophlebium (Blume) C. Presl

This tribe contains only one genus, Goniophlebium, in a broad sense following the latest treatment (Kreier et al., 2008; PPG I, 2016). The distinguishing characters of Goniophlebium include simple-veined, longitudinal sclerenchyma strands in the rhizome and deltoid, pseudopeltate and clathrate rhizome scales (Rödl-Linder, 1990). However, some authors (Zhang et al., 2013) prefer to adopt concepts recognizing several smaller genera. These classifications recognize, besides Goniophlebium sensu stricto, the genera Metapolypodium, Polypodiastrum, and Polypodiodes. The type species of these small genera are in different well-supported subclades which indicates consistency between small genera classification and our inferred phylogenetic relationships (Fig. 1, Table 4). However, the current sampling of Goniophlebium is rather incomplete and a denser sampling is needed to address the arguments presented by Rödl-Linder (1990).

Tribe Lecanoptereae C.C. Chen \& H. Schneider, trib. nov. -TYPE: Lecanopteris Reinw.

There are four clades in this group. In addition to the genus Lecanopteris, the three clades MG1, MG2, and MG3 contain species that were treated either as Colysis or Microsorum in the past. Of them, the MG1 clade contains two species in this study, Asian Microsorum membranaceum and M. lastii from Madagascar. In addition, a further putative member of this clade is arguably the Madagascan endemic $M$. leandrianum Tardieu (Kreier et al., 2008). These species within MG1 have unique plastid genome, biogeography, and morphological characters such as extremely thin 
and membranaceous lamina, and have been named Bosmania Testo in the most recent study (Testo et al., 2019). The clades MG2 and MG3 consist of species mainly distributed in Oceania, especially Australia and New Zealand and Lecanopteris is mainly a southeast Asian and Malaysian genus with highly distinct morphological features (i.e. intercellular cavities in the rhizome) related to their relationships with ants (Haufler et al., 2003).

Our results show Lecanopteris, MG2, and MG3 as each being monophyletic and highly supported whether alone or together (Fig. 1). Lecanopteris and MG3 are monophyletic and sister of MG2. This structure is congruent with the previously results (Testo \& Sundue, 2014; Nitta et al., 2018). However, another relationship with Lecanopteris and MG2 as sisters and together forming a sister clade of MG3 has been found (Schneider et al., 2006; Testo et al., 2019).

The delimitation and the possible new ranks of the three clades Lecanopteris, MG2 and MG3 are discussed here with three options. First, each of the three clades represents a different genus; this would keep the current definition and scope of Lecanopteris with another two generic names to stand for MG2 and MG3. Of them, the generic name Dendroconche Copel. will be applied for MG3 withthe type D. annabellae (H.O. Forbes) Copel. (= M. linguiforme). This has been published recently (Testo et al., 2019), with the new generic name Zealandia Testo \& A. R. Field also for MG2.

Second, extending the genus Lecanopteris to include also MG3 and another generic namefor MG2 (Zealandia). Although clade MG3 does not have the apomorphic characters of the ant fern genus Lecanopteris (i.e. cavities in the rhizome), one of the species, Microsorum linguiforme, occasionally has internal rhizome cavities that might be interpreted as being homologous with the cavities found in Lecanopteris (Bosman, 1991; Haufler et al., 2003). In addition, the ants are observed living under the rhizomes of some plants of Colysis ampla (=Dendroconche ampla) (Testo et al., 2019). External ant housing is also found in Lecanopteris mirabilis which is a sister of the species of Lecanopteris with intrarhizome ant housing. Rhizome cavities have not been found in the any of the species comprising MG2 so far. Despite of this ambiguity, this option is less suitable because robust support for the clade is lacking as mentioned above; more samples and studies of morphological characters are still needed.

The last option is to extend Lecanopteris to include both MG2 and MG3 forming Lecanopteris sensu lato. The geographical range (Oceania for MG2 and MG3) and intercellular cavities (Lecanopteris) may roughly distinguish this clade from the other microsoroid ferns, but this large genus would still perhaps not be the best option because it would be morphologically poorly defined (Schneider et al., 2006; Testo et al., 2019). 
Tribe Microsoreae V.N.Tu; Novosti Sist. Vyssh. Rast. 18: 18, 1981 —TYPE:

Microsorum Link

This tribe has also been found in previous studies containing the main clades of the core Microsorum species, although the subdivision of the tribe was not solved due to limited sampling and markers (Kreier et al., 2008; Nitta et al., 2018). In the present study we found four clades consisting of core Microsorum, MG4, Leptochilus, and MG5. Of them, the former two clades, and the latter two clades are sisters to each other (Fig. 1).

The core Microsorum clade contains two type species, M. punctatum and $M$. scolopendria, representing the genera Microsorum and Phymatosorus, respectively. Several authors have accepted Phymatosorus as a distinct genus based on the morphological characters such as anadromous tertiary vein and superficial or sunken sori (Hennipman et al., 1990; Bosman, 1991), but it is not a monophyletic group in our phylogenetic tree (Fig. 1). In addition to the type species in the core Microsorum clade, the species of Microsorum can be found also in another two clades, MG4, MG5 of Microsoreae. The generic name Phymatosorus could be applied for the branch with the type species but this would require several new generic names to be created. Besides, hybrids occur frequently between this and the species of its sister branch (Nitta et al., 2018). Therefore, it is better to merge Phymatosorus under the generic name

\section{Microsorum.}

The clade Leptochilus includes many type species representing various genera that have previously been considered distinct, such as Colysis, Kontumia, Kaulinia, Myuropteris, Nistarika, and Paraleptochilus (Table 4). The species within this clade are morphologically diverse. Leptochilus macrophyllus appears to have diverged first followed by L. pteropus (widely known as Microsorum pteropus) and the rest of the species. Our results are congruent with those recently found by Zhang et al. (2019). The tribe Microsoreae is monophyletic but it would not be suitable to combine all four clades under one genus because of the large number and diversity of the species. Instead, suitable subdivisions would be needed. The species of Leptochilus are mostly terrestrial unlike those of Microsorum that are mostly epiphytes. This would lend support for maintaining its generic status. However, this would automatically create a paraphyletic Microsorum and thus new generic names would be needed for the clades MG4 and MG5. At this point no such names are proposed because we think that more detailed studies, including morphological characters, are needed to provide robust delimitation for these clades, and the core Microsorum.

Tribe Lepisoreae Ching ex E Hennipman, P Veldhoen \& KU Kramer; Fam. Gen. Vasc. Pl. I: 207, 1990 -TYPE: Lepisorus (J.Sm.) Ching 
The tribe Lepisoreae contains seven well-supported clades, with each of them representing a genus recognized in PPG I (2016). Paragramma is the first clade and following two large clades which consist of the rest six genera. One of large clades is composed of five smaller genera: Lemmaphyllum, Neolepisorus, Tricholepidium, Neocheiropteris, and Lepidomicrosorium. The other main clade includes only one large and diverse genus, Lepisorus. Wang et al. (2010a) divided Lepisorus into nine subclades, which is congruent with our results (Fig. 2). The species L. accedens (=Weatherbya accedens) was recently supported as being embedded in the genus Lepisorus (Wei et al., 2017), and our results show it as sister to the subclade III but with weak support (Fig. 2; aLRT $=71.3 \% /$ aBayes $=0.75 /$ UFBoot $=98.0 \% / \mathrm{PP}=$ $0.86)$.

\section{Summary}

Our efforts to infer a phylogeny of the microsoroid ferns, with sampling of over $70 \%$ of the species, provided support for the tribes as presented above. Of the five new groups of the microsoroid ferns that differ from the current genera of PPGI (2016), MG1-MG3 are recently provided the generic names Bosmania, Zealandia, and Dendroconche, respectively (Testo et al., 2019). However, MG4 and MG5, which have been included in the genera Microsorum and Phymatosorus, need further more detailed study including also morphological characters in order to provide a practical and useful classification. In addition to these two groups, the species delimitation such as for Lepidomicrosorium superficiale needs also further work. We found the markers atpA and $m a t K$ to provide useful information for inferring phylogeny of the microsoroid ferns, but the number of sampled terminals for these two is still very limited. In addition, nuclear markers should be considered as well since they have revealed introgression or hybridization deeper in the tree (Nitta et al., 2018).

\section{ACKNOWLEDGEMENTS}

The authors acknowledge the financial support by the Chinese Academy of Sciences to HS. They also acknowledge the support by the molecular laboratory facilities team and fresh material assistance from XTBG. In addition, we appreciate colleagues Cheng-Wei Chen, Li-Yaung Kuo, Chun-Ming Chen, Daniele Cicuzza and Xianchun Zhang for providing important material.

\section{REFERENCES}

Anisimova, M., Gil, M., Dufayard, J.F., Dessimoz, C., Gascuel, O., 2011. Survey of branch support methods demonstrates accuracy, power, and robustness of fast-likelihood-based approximation scheme. Syst. Biol. 60, 685-699. https://doi.org/10.1093/sysbio/syr041. 
Bosman, M., 1991. A monograph of the fern genus Microsorum (Polypodiaceae), including an attempt towards a reconstruction of the phylogenetic history of the microsoroids. Leiden Bot. Ser. 14, 1-161.

Brownsey, P.J., Perrie, L.R., 2014. Polypodiaceae (excluding Notogrammitis). In: Breitwieser, I., Heenan, P.B., Wilton, A.D. Flora of New Zealand - Ferns and Lycophytes. Fascicle 1. Manaaki Whenua Press, Lincoln.

Edger, R.C., 2004. MUSCLE: multiple sequence alignment with high accuracy and high throughput. Nucleic Acids Res. 32, 1793-1797.

Farris, J.S., Albert, V.A., Källersjö, M., Lipscomb, D., Kluge, A.G., 1996. Parsimony jackknifing outperforms neighbor-joining. Cladistics 12, 99-124.

Fraser-Jenkins, C.R., 2008. Taxonomic revision of three hundred Indian subcontinental Pteridophytes: with a revised census list; a new picture of fern-taxonomy and nomenclature in the Indian subcontinent. Bishen Singh Mahendra Pal Singh.

Goloboff, P.A., 1999. Analyzing large data sets in reasonable times: solutions for composite optima. Cladistics 15, 415-428.

Goloboff, P. A., Farris, J. S., Nixon, K., 2008. TNT, a free program for phylogenetic analysis. Cladistics 24, 774-786.

Goloboff, P. A., Catalano, S. A., 2016. TNT version 1.5, including a full implementation of phylogenetic morphometrics. Cladistics 32, 221-238.

Guindon, S., Dufayard, J.F., Lefort, V., Anisimova, M., Hordijk, W., Gascuel, O., 2010. New algorithms and methods to estimate maximum-likehood phylogenies: assessing the performance of PhyML 3.0 Syst. Biol. 5, 307-321. https://doi.org/10.1093/sysbio/syq010.

Hall, T.A., 1999. BioEdit: a user-friendly biological sequence alignment editor and analysis program for Windows 95/98/NT. Nucl. Acids. Symp. Ser. 41, 95-98.

Hasebe, M., Omori, T., Nakazawa, M., Sano, T., Kato, M., Iwatsuki, K., 1994. rbcL gene sequences provide evidence for the evolutionary lineages of leptosporangiate ferns. Proc. Natl. Acad. Sci. U.S.A. 91, 5730-5734.

Haufler, C.H., Grammer, W.A., Hennipman, E., Ranker, T.A., Smith, A.R., Schneider, H., 2003. Systematics of the ant-fern genus Lecanopteris (Polypodiaceae): testing phylogenetic hypotheses with DNA sequences. Syst. Bot. 28, 217-228.

Hennipman, E., Veldhoen, P., Kramer, K.U., Price, M.G., 1990. Polypodiaceae, in: Kramer, K.U. and Green, P.S. (Eds), The families and genera of vascular plants. Vol. I. Pteridophytes and gymnosperms. Springer-Verlag, Berlin. Pp.203-230.

Hetterscheid, W.L.A., Hennipman, E., 1984. Venation patterns, soral characteristics, and shape of the fronds of the microsorioid Polypodiaceae. Meded. bot. Mus. Herb. Rijksuniv. Utrecht. 540, 11-47.

Holttum, R.E., 1966. New ferns from Malesia. Kew Bull. 20, 455-460.

Kalyaanamoorthy, S., Minh, B.Q., Wong, T.K., von Haeseler, A., Jermiin, L.S., 2017. ModelFinder: fast model selection for accurate phylogenetic estimates. Nat. Methods 14, 587-589. https://doi.org/10.1038/nmeth.4285.

Kaulfuss, G.F., 1824. Enumeratio filicum quas in itinere circa terram legit $\mathrm{Cl}$. Adalbertus de Chamisso adiectis in omnia harum plantarum genera permultasque species non satis cognitas vel novas animadversionibus. Sumtibus Caroli Cnobloch, Leipzig.

Kim, C., Zha, H.G., Deng, T., Sun, H., Wu, S.G., 2013. Phylogenetic position of Kontumia (Polypodiaceae) inferred from four chloroplast DNA regions. J. Syst. Evol. 51, 154-163.

Kreier, H.P., Zhang, X.C., Muth, H., Schneider, H., 2008. The microsoroid ferns: Inferring the relationships of a highly diverse lineage of Paleotropical epiphytic 
ferns (Polypodiaceae, Polypodiopsida). Molec. Phylogenet. Evol. 48, 1155-1167.

Kuo, L.Y., Li, F.W., Chiou, W.L., Wang, C.N., 2011. First insights into fern matK phylogeny. Molec. Phylogenet. Evol. 59, 556-566.

Lanfear, R., Frandsen, P.B., Wright, A.M., Senfeld, T., Calcott, B., 2016.

PartitionFinder 2: new methods for selecting partitioned models of evolution formolecular and morphological phylogenetic analyses. Molec. Biol. Evol. 34(3), 772-773. https://doi.org/10.1093/molbev/msw260.

Lehtonen, S., 2011. Towards resolving the complete fern tree of life. PLoS One 6, e24851. https://doi.org/10.1371/journal.pone.0024851.

Li, C., Lu, S., Yang, Q., 2004. Asian origin for Polystichum (Dryopteridaceae) based on rbcL sequences. Chin. Sci. Bull. 49, 1146-1150.

Link H.F., 1833. Hortus regius botanicus berolinensis descriptus, Berolini.

Maddison, W.P., Maddison, D.R., 2017. Mesquite: a modular system for evolutionary analysis. Version 3.31. http://mesquiteproject.org.

Minh, B.Q., Guyen, M.A.T., von Haessler, A., 2013. Ultrafast approximation for phylogenetic bootstrap. Molec. Biol. Evol. 30, 1188-1195. https://doi.org/10.1093/molbev/mst024.

Nayar, B.K., 1964. Kaulinia, a new genus of Polypodiaceous ferns. Taxon 13: 67-69.

Nguyen, L.T., Schmidt, H.A., von Haeseler, A., Ming, B.Q., 2014. IQ-Tree: a fast and effective stochasitc algorithm for estimating maximum-likelihood phylogenies. Molec. Biol. Evol. 32, 268-274. https://doi.org/10.1093/molbev/msu300.

Nitta, J.H., Amer, S., Davis, C.C., 2018. Microsorum $\times$ tohieaense (Polypodiaceae), a New Hybrid Fern from French Polynesia, with Implications for the Taxonomy of Microsorum. Syst. Bot. 43, 397-413.

Nixon, K.C., 2002. Winclada, Version 1.00.08. Software published by the author, Ithaca, NY. Available on-line @ www.diversityof life.org/winclada/.

Nixon, K.C., Davis, J.I., 1991. Polymorphic taxa, missing values and cladistic analysis. Cladistics 7, 233-241.

Nooteboom, H.P., 1997. The microsoroid ferns (Polypodiaceae). Blumea 42, 261-395.

Pichi Sermolli, R.E.G., 1973. Fragmenta pteridologiae (IV). Webbia 28, 445-477.

Platnick, N.I., Griswold, C.E., Coddington, J.A., 1991. On missing entries in cladistic analysis. Cladistics 7, 337-343.

PPG I, 2016. A community-derived classification for extant lycophytes and ferns. J. Syst. Evol. 54, 563-603. https://doi.org/10.1111/jse.12229.

Rambaut, A., Drummond, A.J., 2007. Tracer v.1.4. Available from http://beast.bio.ed.ac.uk/Tracer.

Rödl-Linder, G., 1990. A monograph of the fern genus Goniophlebium. Blumea 34, 277-423.

Rödl-Linder, G., 1994. A monograph of the fern genus Thylacopteris (Polypodiaceae). Blumea 39: 351-364.

Ronquist, F., Huelsenbeck, J.P., 2003. MRBAYES 3: Bayesian phylogenetic inference under mixed models. Bioinformatics 19, 1572-1574.

Schneider, H., Ranker, T.A., Russell, S.J., Cranfill, R., Geiger, J.M.O., Aguraiuja, R., Wood, K.R., Grundmann, M., Kloberdanz, K., Vogel, J.C., 2005. Origin of the endemic fern genus Diellia coincides with the renewal of Hawaiian terrestrial life in the Miocene. Proc. R. Soc. Lond., B, Biol. Sci. 272(1561), 455-460.

Schneider, H., Kreier, H.P., Perrie, L.R., Brownsey, P.J., 2006. The relationships of Microsorum (Polypodiaceae) species occurring in New Zealand. N.Z. J. Bot. 44, 
121-127.

Schneider, H., Janssen, T., Hovenkamp, P., Smith, A.R., Cranfill, R., Haufler, C.H., Ranker, T.A., 2004a. Phylogenetic relationships of the enigmatic Malesian fern Thylacopteris (Polypodiaceae, Polypodiidae). Int. J. Plant Sci. 165, 1077-1087.

Schneider, H., Smith, A.R., Cranfill, R., Hildebrand, T.J., Haufler, C.H., Ranker, T.A., 2004b. Unraveling the phylogeny of polygrammoid ferns (Polypodiaceae and Grammitidaceae): exploring aspects of the diversification of epiphytic plants. Molec. Phylogenet. Evol. 31, 1041-1063.

Schuettpelz, E., Korall, P., Pryer, K.M., 2006. Plastid atpA data provide improved support for deep relationships among ferns. Taxon 55, 897-906.

Schuettpelz, E., Pryer, K.M., 2007. Fern phylogeny inferred from 400 leptosporangiate species and three plastid genes. Taxon 56, 1037-1037.

Small, R.L., Lickey, E.B., Shaw, J., Hauk, W.D., 2005. Amplification of noncoding chloroplast DNA for phylogenetic studies in lycophytes and monilophytes with a comparative example of relative phylogenetic utility from Ophioglossaceae. Molec. Phylogenet. Evol. 36, 509-522.

Smith, A.R., Pryer, K.M., Schuettpelz, E., Korall, P., Schneider, H., Wolf, P.G., 2006. A classification for extant ferns. Taxon 55, 705-731.

Taberlet, P., Gielly, L., Pautou, G., Bouvet, J., 1991. Universal primers for amplification of three non-coding regions of chloroplast DNA. Plant Mol. Biol. 17, 1105-1109.

Testo, W.L., Field, A.R., Sessa, E.B., Sundue, M., 2019. Phylogenetic and Morphological Analyses Support the Resurrection of Dendroconche and the Recognition of Two New Genera in Polypodiaceae Subfamily Microsoroideae. Systematic Botany 44, 1-16.

Trewick S.A., Morgan-Richards, M., Russell, S.J., Henderson, S., Rumsey, F.J., Pínter, I., Barrett, J.A., Gibby, M., Vogel, J.C., 2002. Polyploidy, phylogeography and Pleistocene refugia of the rockfern Asplenium ceterach: evidence from chloroplast DNA. Mol. Ecol. 11, 2003-2012.

Trifinopoulos, J., Nguyen, L.T., von Haesler, A., Minh, B.Q., 2016. W-IQ-Tree: a fast online phylogeneticc tool for maximum likelihoodd analysis. Nucleic Acid Res. 44, W232-W235. https://doi.org/10.1093/nar/gkw256.

Wang, L., Qi, X.P., Xiang, Q.P., Heinrichs, J., Schneider, H., Zhang, X.C., 2010a. Phylogeny of the paleotropical fern genus Lepisorus (Polypodiaceae, Polypodiopsida) inferred from four chloroplast DNA regions. Molec. Phylogenet. Evol. 54, 211-225.

Wang, L., Schneider, H., Zhang, X.C., Xiang, Q.P., 2012. The rise of the Himalaya enforced the diversification of SE Asian ferns by altering the monsoon regimes. BMC Plant Biol. 12, 210.

Wang, L., Wu, Z.Q., Xiang, Q.P., Heinrichs, J., Schneider, H., Zhang, X.C., 2010b. A molecular phylogeny and a revised classification of tribe Lepisoreae (Polypodiaceae) based on an analysis of four plastid DNA regions. Bot. J. Linn. Soc. 162, 28-38.

Wang, L., Wu, Z.Q., Bystriakova, N., Ansell, S.W., Xiang, Q.P., Heinrichs, J., Schneider H., Zhang, X.C., 2011. Phylogeography of the Sino-Himalayan fern Lepisorus clathratus on "the roof of the world". PLoS One 6(9), e25896. https://doi.org/10.1371/journal.pone.0025896.

Wei, X.P., Wei, R., Zhao, C.F., Zhang, H.R., Zhang, X.C., 2017. Phylogenetic Position of the Enigmatic Fern Genus Weatherbya (Polypodiaceae) Revisited: Evidence from Chloroplast and Nuclear Gene Regions and Morphological Data. Int. 
J. Plant Sci. 178, 450-464.

Wheeler, W.C., 2012. Systematics: a course of lectures. John Wiley \& Sons.

Wheeler, W.C. et al., 2017. The spider tree of life: phylogeny of Araneae based on target-gene analyses from an extensive taxon sampling. Cladistics 33, 574-616.

Wolsan, M., Sato, J.J., 2010. Effects of data incompleteness on the relative performance of parsimony and Bayesian approaches in a supermatrix phylogenetic reconstruction of Mustelidae and Procyonidae (Carnivora). Cladistics 26, 168-194.

Wu, S.G., Pan, K.L., Xiang, J.Y., 2005. A new genus and two new species of ferns from Vietnam. Novon 15: 245-249.

Zhang, L., Lu, N.T., Zhou, X.M., Chen, D.K., Knapp, R., Zhou, L., Guo, L., Luong, T.T., Sun, H., Gao, X.F., Zhang, L. B. (2019). A plastid phylogeny of the Old World fern genus Leptochilus (Polypodiaceae): Implications for cryptic speciation and progressive colonization from lower to higher latitudes. Molec. Phylogenet. Evol. 134, 311-322.

Zhang, X.C., Lu, S.G., Lin, Y.X., Qi, X.P., Moore, S.J., Xing, F.W., Wang, F.G., Hovenkamp, P.H., Gilbert, M.G., Nooteboom, H.P., Parris, B.S., Haufler, C.H., Kato, M., Smith, A.R., 2013. Polypodiaceae. In: Wu, Z.Y., Raven, P.H., Hong, D.Y. (Eds.) Flora of China. Vol. 2-3. Beijing: Science Press and St. Louis: Missouri Botanical Garden Press, pp. 758-850. 


\section{Color should be used only for Figure 4 in print.}

Table 1 Summary of sampled specimens. Specimen information is organized as follows: locality or cultivated, collector or specimen number, and herbaria abbreviations which are given in parenthesis following the Index Herbariorum. GenBank Accession Numbers for six plastid regions: rbcL, rps 4 \& rps4-trnS, trnL \& trnL-trnF, atpA, atpB \& rbcL-atpB, matK. The dash indicates missing sequence. Sequences IN BOLD are novel; marked with ${ }^{* *}$ were downloaded from Genbank as complete genome, which were used to extract data of each regions used in this study.

Table 2 List of primers for amplifying the gene regions used in this study.

Table 3 Information of alignment dataset, best-fitting models and parameter values of large and small dataset for separate genes of $r b c L, r p s 4 \&$ rps4-trnS IGS, trnL-trnF region, atpA, atpB \& rbcL-atpB IGS, and matK.

Table 4 The proposed generic names, following the status of the name which based on the Tropicos database (https://www.tropicos.org/), type species \& if it included in this study. Group indicates the clade that the type species of the genus belongs to; Mono indicates if the genus is monophyletic or not, and mark* means only one species in this study; the last column shows original and lectotype publications. Names in bold used in this study. Abbreviation: leg., legitimate; nom. cons., conserved name; nom. rej., name rejected; illeg. hom., name illegitimated due to homonymy; LT, lectotype; -, lack of data.

Table 5 List of generic name and grouping of the microsoroid ferns in selected taxonomic and phylogenetic works. Abbreviations: GO, goniophlebioid clade; LC, lecanopteroid clade; LP, lepisoroid clade; ME, membranaceoid clade; MI, microsoroid s.s. clade; TH, thylacopteroid clade; Sf.LO, Subfamily Loxogrammoideae; Sf.DN, Subfamily Drynarioideae; Sf.MI, Subfamily Microsoroideae; T.PO, Tribe Polypodieae; T.LP, Tribe Lepisoreae; T.MI, Tribe Microsoreae; T.GO, Goniophlebieae; T.TH, Thylacoptereae; T.LC, Lecanoptereae. 
Fig. 1 Phylogenetic hypothesis depicting the phylogenetic relationships of the tribes Thylacoptereae, Goniophlebieae, Lecanoptereae, and Microsoreae. The generic names with square brackets indicate the latest results (Testo et al., 2019) that are not included in PPG I (2016). Branch lengths correspond to the estimated number of substitution events. The values are for the Shimodaira-Hasegawa-like approximate likelihood ratio test (SH-aLRT, \%), p-values of the Bayesian-like transformation of aLRT statistics (abayes), ultrafast bootstrap analysis (UFBoot, \%), and posterior confidence values of $\mathrm{BI}$ (pp) respectively. The asterisk, *, indicates branches with maximum values of the indices used.

Fig. 2 Phylogenetic hypothesis depicting the phylogenetic relationships of the tribe Lepisoreae, branch lengths correspond to the estimated number of substitution events. Subgroups from I to IX are based on the results of Wang et al. (2010b). The values as in Fig. 1. with the asterisk, *, indicating branches with maximum values of the indices.

Fig. 3 Phylogenetic hypothesis depicting the phylogenetic relationships of the microsoroid ferns in small dataset, branch length correspond to the estimated number of substitution events. The values as in Fig. 1. with the asterisk, *, indicating branches with maximum values of the indices.

Fig. 4 Phylogenetic hypothesis depicting the phylogenetic relationships based on three large datasets. Three of the main groups or genera: core Microsorum, Lepisorus, and Lepidomicrosorium are showed also partly with their subclades indicated with purple, blue, and yellow colors. In addition, genus Paragramma is highlighted in red. The small squares above the branches indicate different values of ShimodairaHasegawa-like approximate likelihood ratio test (SH-aLRT), p-values of the Bayesian-like transformation of aLRT statistics (abayes), and ultrafast bootstrap analysis (UFBoot), respectively. The black color indicates values $=1.00(100 \%)$ in all tests; the gray color indicates the values $<1.00(100 \%)$ and $>=0.95(95 \%)$ in abayes and UFBoot, whereas $<100 \%$ and $>=80 \%$ in SH-aLRT; and white the values $<0.95$ $(95 \%)$ in abayes and UFBoot, whereas $<80 \%$ in SH-aLRT. Geographical abbreviations: TW, Taiwan; JP, Japan; and YN, Yunnan (China).

Fig. 5 Consensus of 1714 equally parsimonious trees with a length of 7677 steps from the maximum parsimony analysis based on the large dataset (combining six gene regions). Subgroups from I to IX are based on the results of Wang et al. (2010b). The genera with square brackets are based on the results of Testo et al. (2019). 


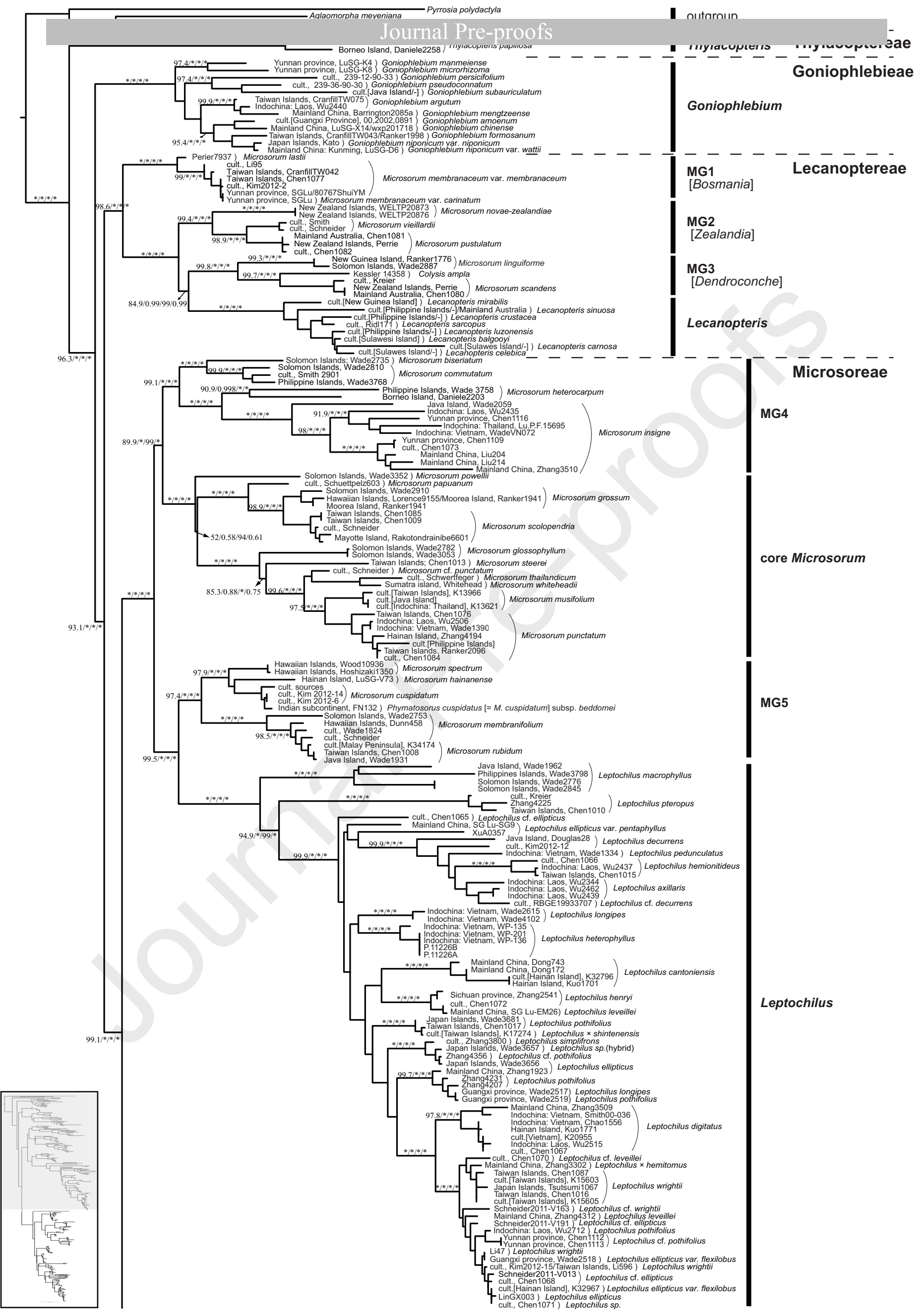




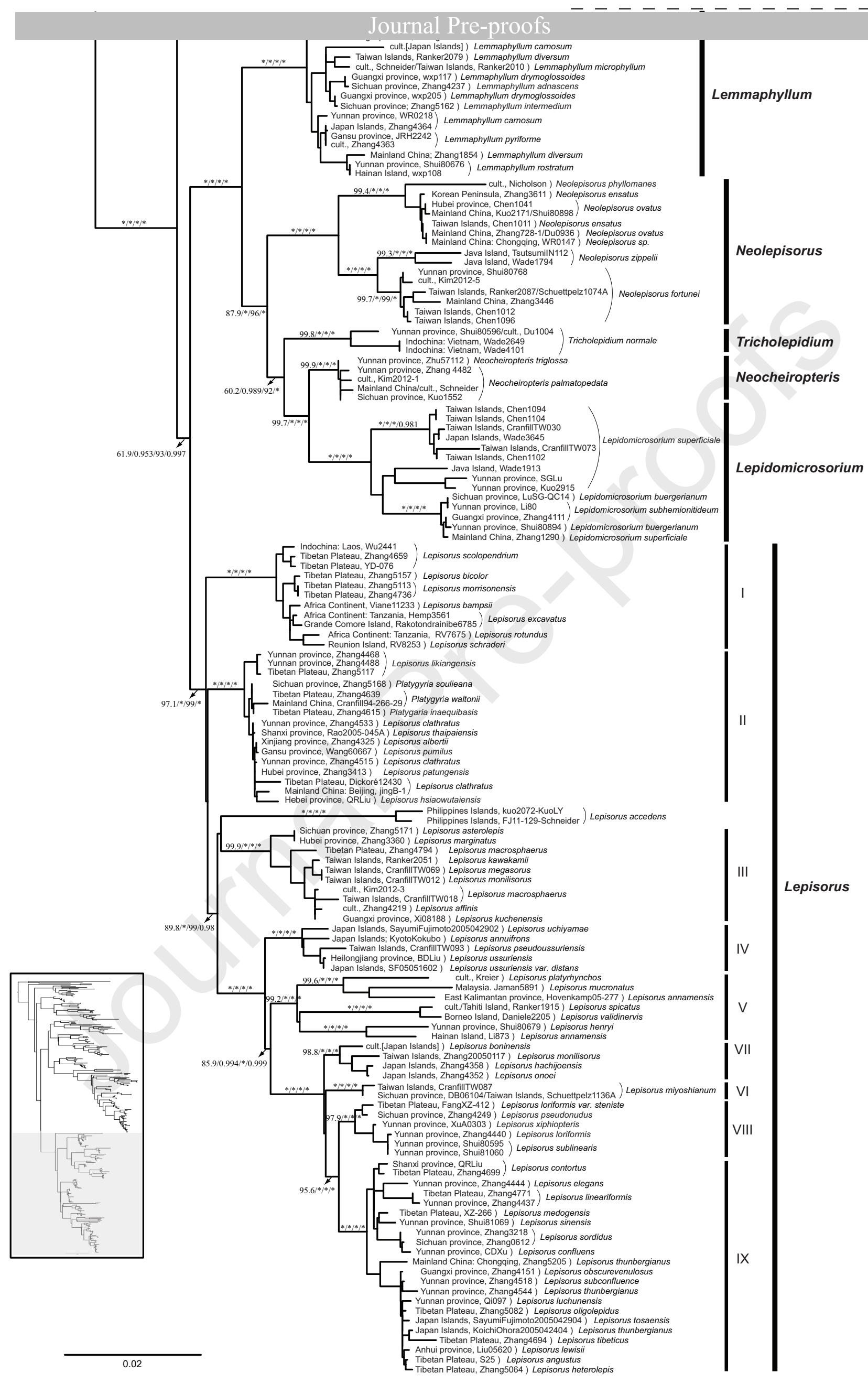




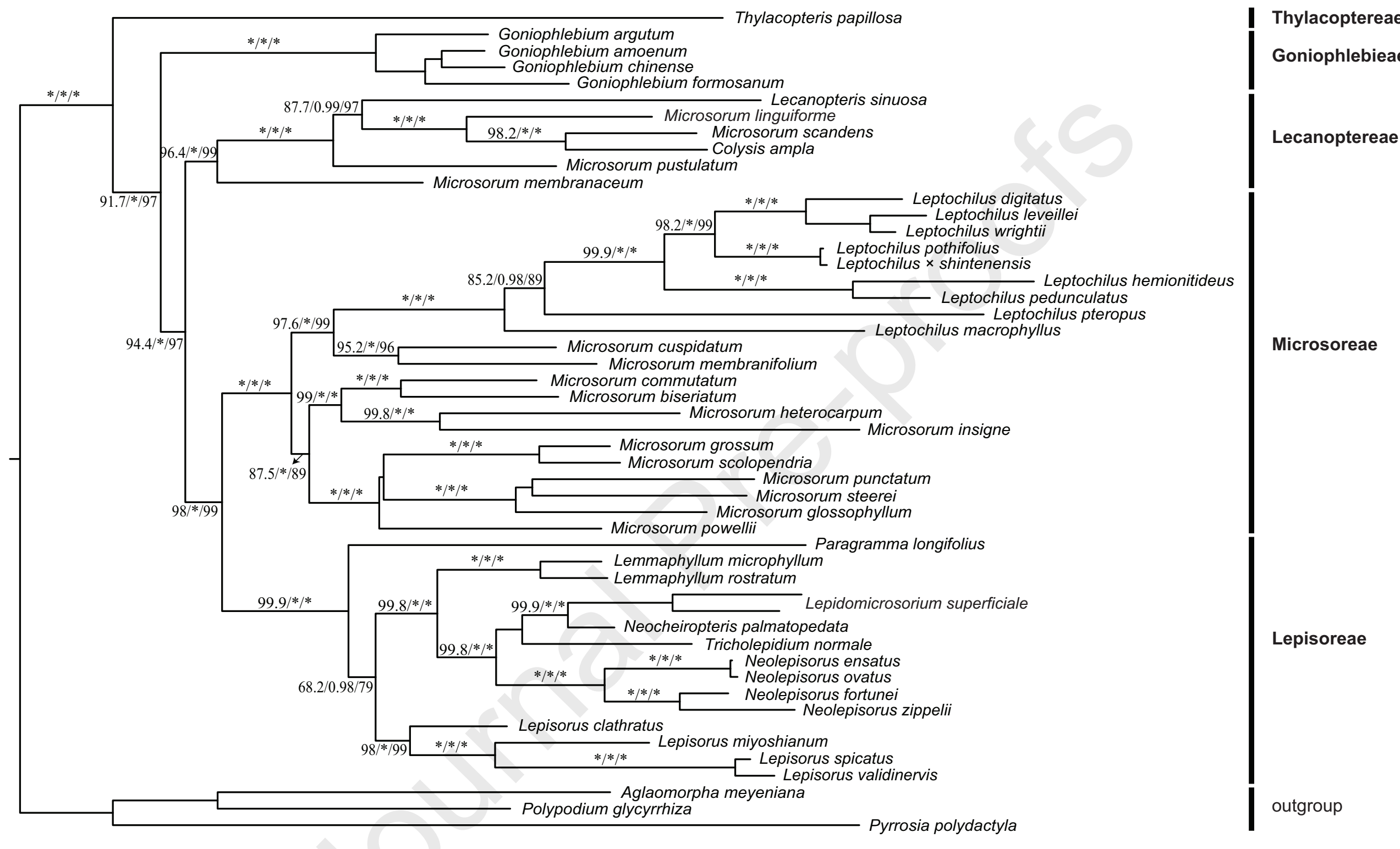




\section{three-combination}

(rbcL, rps4 + rps4-trnS, trnL+trnL-trnF)

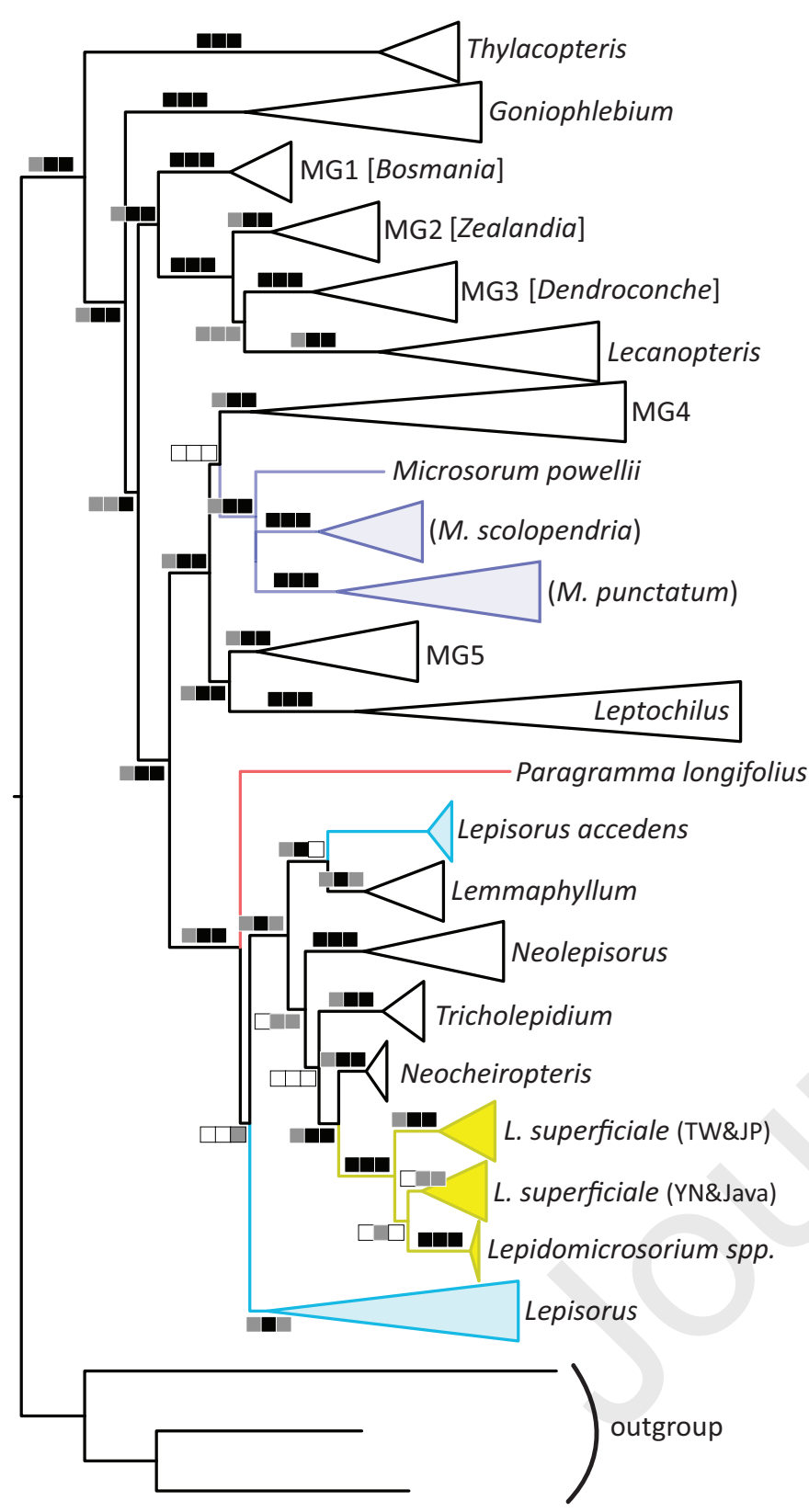

\section{four-combination}

(rbcL, rps4 + rps4-trnS, trnL+trnL-trnF, rbcL-atpB + atpB)

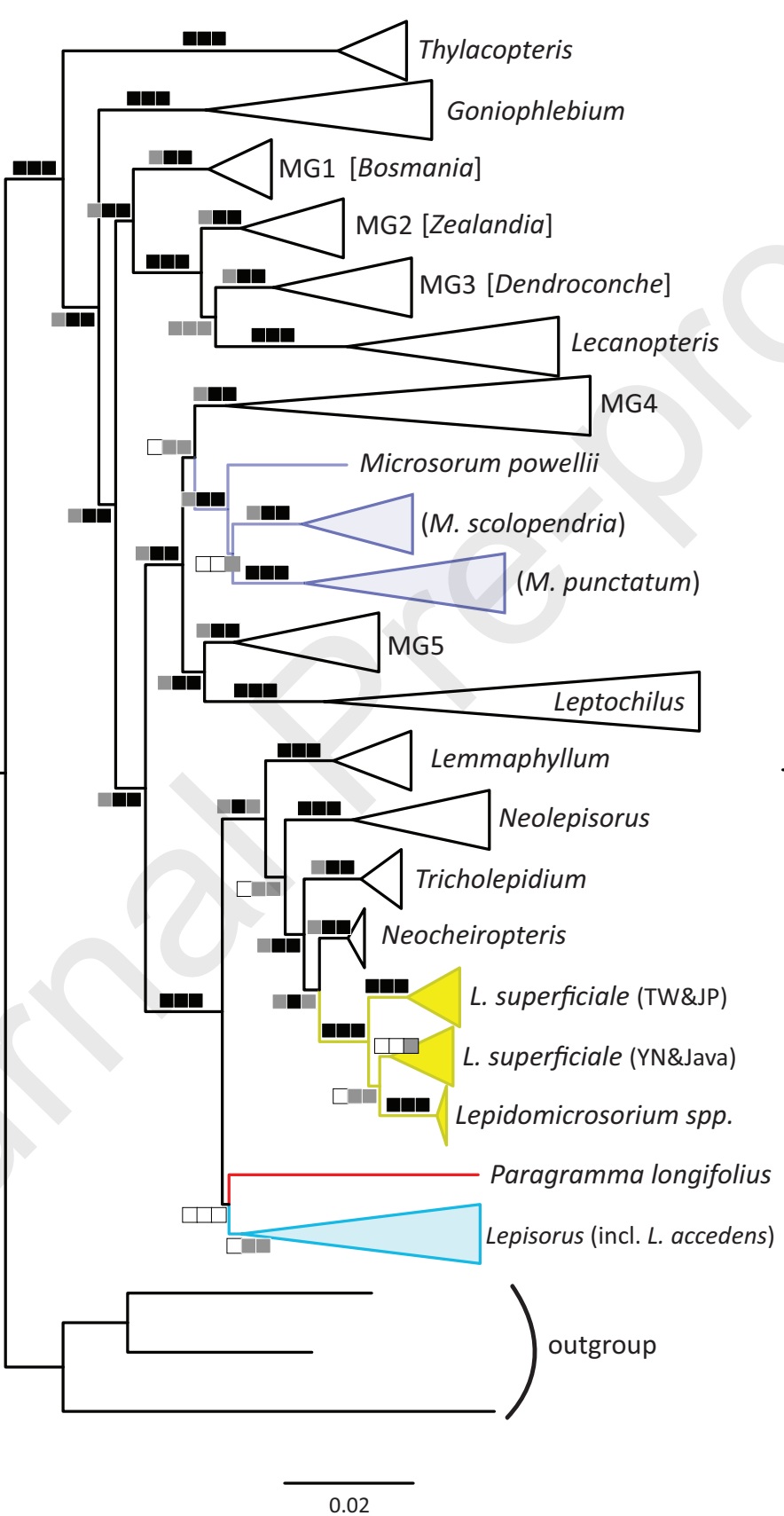

\section{six-combination}

(rbcL, rps4 + rps4-trnS, trnL+trnL-trnF, rbcL-atpB + atpB, atpA, matK)

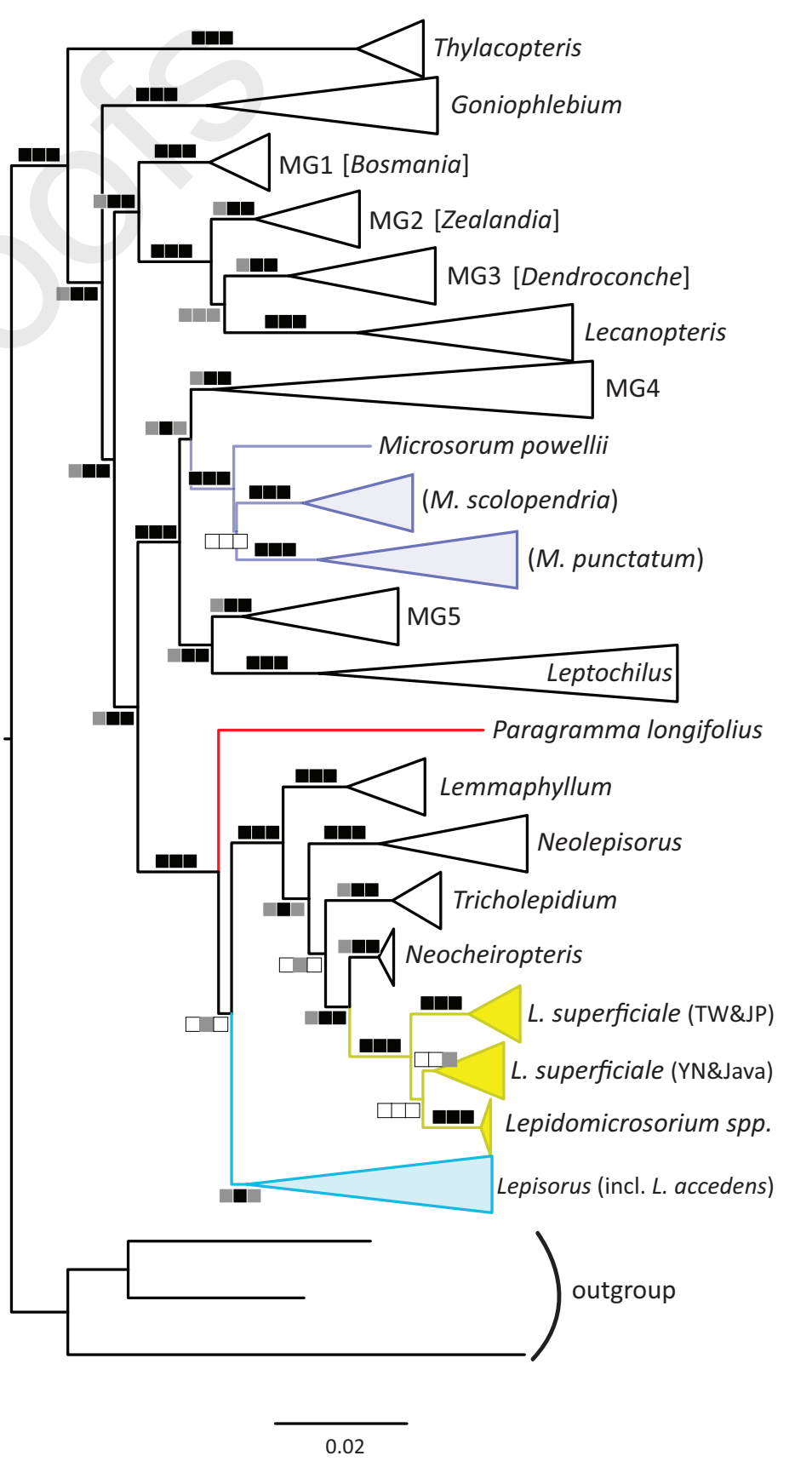




\section{Journal Pre-proofs}

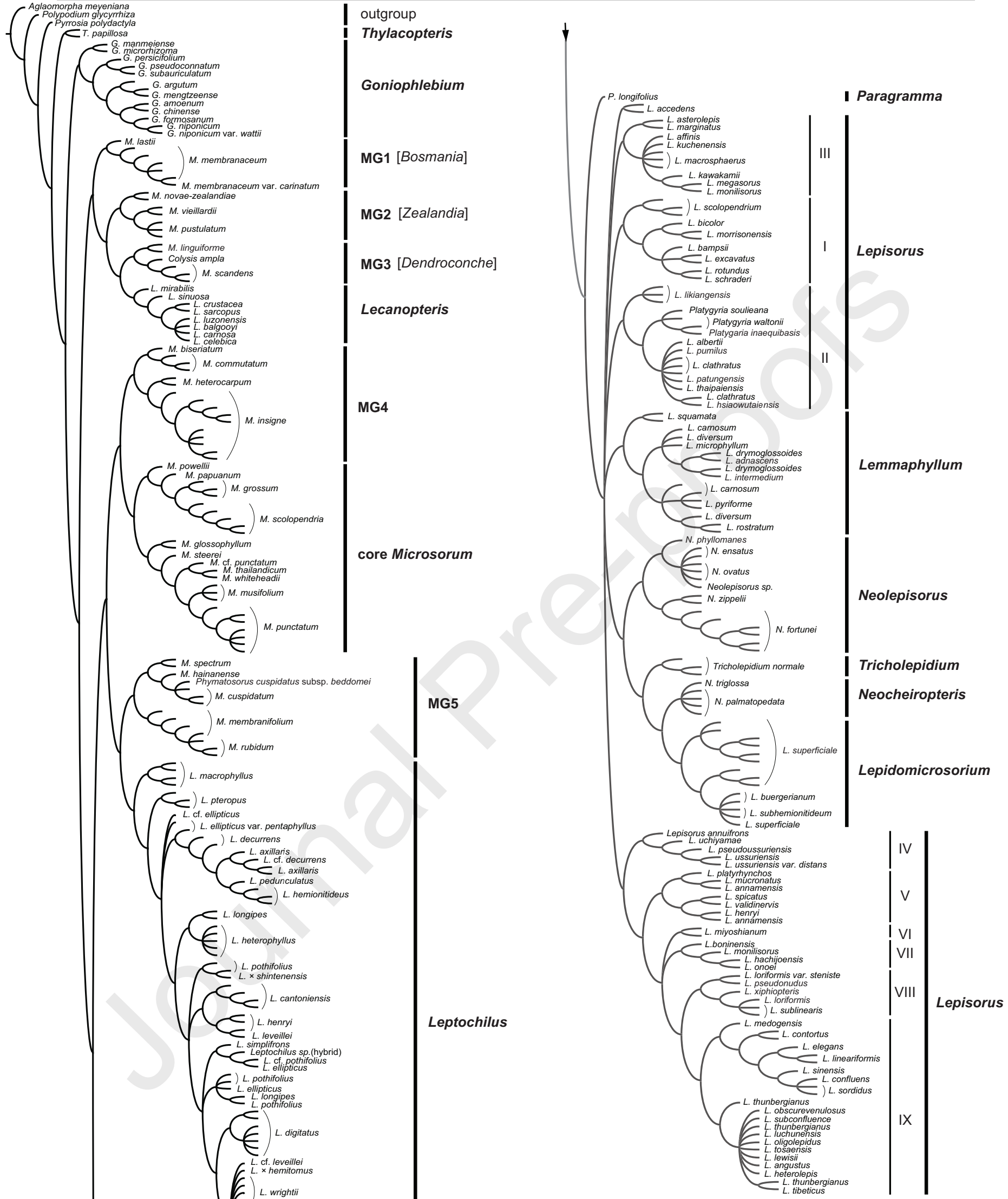


Table 1 Summary of sampled specimen. Specimen information is organized as follows: locality, collector or specimen number (deposited herbarium). GenBank Accession Numbers for six plastid regions: rbcL, rps4 \& rps4-trnS, trnL \& trnL-trnF, atpA, atpB \& rbcL-atpB, matK. A dash indicates missing sequence. Sequences IN BOLD are novel; marked with * were downloaded from Genbank as complete genome, which were used to extract data of each regions used in this study.

Abbreviations: BGB, Botanical Garden Berlin-Dahlem; BGG, Old Botancial Garden Göttingen; BGH, Botanical Garden of the University of Heidelberg; BGM, Botanical Garden Munich-Nymphenburg; BGZ, Botanical Garden Zurich; CAG, Garden of Charles Alford; CBG, Cibodas Botanical Garden; DBG, Duke Botanical Garden; JNU, Jinan University; KBCC, Dr. Cecilia Koo Botanic Conservation Center; KBG, Kunming Botanical Garden; LBG, Leiden Botanical Garden; PE, Chinese National
Herbarium; RBGE, Royal Botanic Garden Edinburgh; RBGK, Royal Botanic Gardens Kew; RBGV, Royal Botanic Gardens Victoria; SZBG, Fairylake Botanical Garden; TBG, Tuebingen Botanic Garden; UBDH, Universiti Brunei Darussalam; UBG,

\begin{tabular}{|c|c|c|c|c|c|c|c|}
\hline Taxon name & Voucher of Accession & rbcL & rps4 \& rps4-trns & $\operatorname{trnL} \& \operatorname{trnL}-\operatorname{trnF}$ & atpA & $\begin{array}{c}\text { atpB \& rbcL- } \\
\text { atpB } \\
\end{array}$ & matK \\
\hline \begin{tabular}{|l|} 
Colysis ampla Copel. \\
\end{tabular} & Kessler 14358 (VT) & KF570108 & KF570109 & KF570110 & - & - & - \\
\hline Goniophlebium amoenum (Wall. ex Mett.) Bedd. & cult. XTBG [Guangxi Province]; 00,2002,0891 & MH665028 & MH665091 & MH665158 & MH664988 & MH665004 & MH665018 \\
\hline Goniophlebium argutum (Wall. ex Hook.) J. Sm. ex Hook. & Taiwan Islands; Cranfill TW075 (UC) & DQ164442 & DQ164473 & DQ164505 & - & - & - \\
\hline \begin{tabular}{|l|} 
Goniophlebium argutum (Wall. ex Hook.) J. Sm. ex Hook. \\
\end{tabular} & Indochina: Laos; Wu 2440 (KUN) & $\begin{array}{ll}\mathrm{J} \times 103709 \\
\end{array}$ & JX103751 & JX103793 & - & JX103667 & - \\
\hline \multirow{2}{*}{ Goniophlebium chinense (Christ) X.C. Zhang } & Mainland China: Chongqing; Lu SG-X14 (PYU) & DQ078630 & DQ078637 & & - & - & - \\
\hline & Mainland China; Wei X.P. wxp201718 (IMD) & - & & & - & - & MF450478 \\
\hline \multirow{2}{*}{ Goniophlebium formosanum (Baker) Rodl-Linder } & Taiwan Islands; Cranfill TW043 (UC) & - & AY096224 & DQ642235 & - & 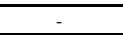 & - \\
\hline & Taiwan Islands; Ranker 1998 (COLO) & - & - & - & EF463813 & EF463495 & - \\
\hline Goniophlebium manmeiense (Christ) Rodl-Linder & Mainland China: Yunnan province; Lu SG-K4 (PYU) & DQ078628 & DQ078631 & - & - & - & - \\
\hline Goniophlebium mengtzeense (Christ) Rodl-Linder & Mainland China; Barrington 2085a (UVM) & AY362560 & AY362627 & - & - & - & - \\
\hline Goniophlebium microrhizoma (C.B. Clarke ex Baker) Bedd. & Mainland China: Yunnan; Lu SG-K8 (PYU) & DQ078627 & DQ078632 & & - & - & - \\
\hline Goniophlebium niponicum (Mett.) Bedd. var. niponicum & Japan Islands; Kato et al. (TI) & - & AY362626 & EU483027 & - & - & - \\
\hline Goniophlebium niponicum var. wattii (Bedd.) Bedd. & Mainland China: Kunming; Lu SG-D6 (PYU) & DQ078625 & DQ078636 & & - & - & - \\
\hline Goniophlebium persicifolium (Desv.) Bedd. & cult. BGB; 239-12-90-33 (B) & EU482933 & EU482978 & $\begin{array}{lll}\text { EU483028 } \\
\end{array}$ & - & - & - \\
\hline Goniophlebium pseudoconnatum (Copel.) Copel. & cult. BGB; 239-36-90-30 (B) & EU482934 & EU482979 & EU483029 & - & - & - \\
\hline \multirow{2}{*}{ Goniophlebium subauriculatum (Blume) C.PresI } & cult. UCBG [Indonesia Islands: Java, (UC)] & AF470342 & -2 & AY083645 & - & - & - \\
\hline & cult. BGG, Kreier s.n. (GOET) & - & DQ168812 & & - & - & - \\
\hline \multirow{2}{*}{ Lecanopteris balgooyi Hennipman } & cult. UBG [Sulawesi Island; David Klein s.n. (L)] & AF470328 & & AY083631 & - & - & - \\
\hline & Sulawesi Island; Hennipman s.n. (L) & - & EU482980 & 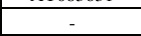 & - & - & - \\
\hline \multirow{2}{*}{ Lecanopteris carnosa (Reinw.) Blume } & |cult. UBG [Sulawesi Island; David Klein s.n. (L)] & AF470322 & & AY083625 & - & - & - \\
\hline & cult. RBGK; Cranfill 153 (UC) & - & AY096227 & - & - & - & - \\
\hline \multirow{2}{*}{ Lecanopteris celebica Hennipman } & cult. UBG 85GR00170 [Sulawesi Island; Hennipman s.n. (L)] & AF470323 & 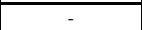 & AY083626 & - & - & - \\
\hline & cult. BGG; Schneider s.n. (GOET) & s.t. & EU482981 & & - & - & - \\
\hline \multirow{2}{*}{ Lecanopteris crustacea Copel. } & cult. UBG 82 GR00292 [Philippine Islands; Franken and Roos 341(L)] & AF470329 & - & AY083632 & - & - & - \\
\hline & cult. CAG; A.R. Smith (UC) & & EU482982 & & - & - & - \\
\hline \multirow{2}{*}{ Lecanopteris luzonensis Hennipman } & cult. UBG [Philippine Islands; Hennipman $7820(\mathrm{U}, \mathrm{L})]$ & AF470325 & & AY083628 & - & - & - \\
\hline & cult. BGG; Schneider s.n. (GOET) & - & EU482983 & & - & - & - \\
\hline Lecanopteris mirabilis (C. Chr.) Copel. & cult. UBG 665 [New Guinea Island; Hennipman s.n. (U)] & AF470330 & EU482984 & AY083633 & - & - & - \\
\hline Lecanopteris sarcopus (Teijsm. \& Binn.) Copel. & cult. RBGE; Ridl 171 (E) & EU482935 & EU482985 & EU483030 & - & - & - \\
\hline \multirow{3}{*}{ Lecanopteris sinuosa (Hook.) Copel. } & cult. UBG 87GR00087 [Philippine Islands; Hennipman 7821 (U, L)] & AF470321 & - & AY083624 & - & - & - \\
\hline & cult. RBGK & - & $\overline{\text { AY362634 }}$ & T1005ost & & & - \\
\hline & Mainland Australia; Sankowsky 4169 (NSW) & - & - & - & KP164484 & KP164491 & - \\
\hline Lemmaphyllum adnascens Ching & Mainland China: Sichuan province; Zhang $4237(\mathrm{PE})$ & GU126694 & GU126713 & GU126724 & - & GU126702 & - \\
\hline Lemmaphyllum carnosum (Wall. ex J. Sm.) C. Presl & cult. UCBG 50.0326 [Japan Islands; (UC)] & AF470332 & AY362631 & AY083635 & - & & - \\
\hline Lemmaphyllum carnosum (Wall. ex J. Sm.) C. Presl & Mainland China: Yunnan province; Wei R et al. WR0218 (PE) & KX891370 & KX891402 & KX891355 & - & KX891384 & - \\
\hline Lemmaphyllum carnosum (Wall. ex J. Sm.) C. Presl & Japan Islands; Zhang 4364 (PE) & GU126698 & GU126717 & GU126728 & - & GU126706 & - \\
\hline Lemmaphyllum drymoglossoides (Baker) Ching & Mainland China: Guangxi province; Wei XP et al. wxp117(PE) & KX891372 & KX891403 & KX891357 & - & KX891385 & - \\
\hline Lemmaphyllum drymoglossoides (Baker) Ching & Mainland China: Guangxi province; Wu L et al. wxp205 (PE) & KX891373 & KX891404 & KX891358 & - & KX891386 & - \\
\hline Lemmaphyllum diversum (Rosenst.) Tagawa & Taiwan Islands; Ranker 2079 (COLO) & EU482937 & EU482987 & EU483032 & - & GU126707 & - \\
\hline Lemmaphyllum diversum (Rosenst.) Tagawa & Mainland China; Zhang $1854(\mathrm{PE})$ & EU482939 & EU482989 & EU483034 & - & - & - \\
\hline Lemmaphyllum intermedium (Ching) Li Wang & Mainland China: Sichuan province; Zhang 5162 (PE) & GU126696 & GU126715 & GU126726 & - & - & - \\
\hline \multirow{2}{*}{ Lemmaphyllum microphyllum C. Presl } & cult. BGZ; Schneider s.n. (GOET) & EU482938 & EU482988 & EU483033 & 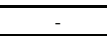 & - & - \\
\hline & Taiwan Islands; Ranker 2010 (COLO) & 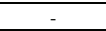 & - & - & EF463824 & EF463496 & - \\
\hline Lemmaphyllum pyriforme (Ching) Ching & Mainland China: Gansu province; Jiang RH JRH2242 (PE) & KX891374 & KX891406 & KX891361 & & KX891388 & - \\
\hline
\end{tabular}




\begin{tabular}{|c|c|c|c|c|c|c|c|}
\hline Lemmaphyllum pyriforme (Ching) Ching & cult. TBG; Zhang 4363 (PE) & GU126695 & GU126714 & GU126725 & - & GU126703 & - \\
\hline Lemmaphyllum rostratum (Bedd.) Tagawa & Mainland China: Yunnan province; Shui $80676(\mathrm{PE})$ & GU126697 & GU126716 & GU126727 & - & & \\
\hline Lemmaphyllum rostratum (Bedd.) Tagawa & Hainan Island; Wei XP et al. wxp108 (PE) & KX891376 & KX891407 & KX891363 & 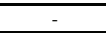 & KX891390 & MF450477 \\
\hline Lemmaphyllum squamatum (A.R. Smith \& X.C. Zhang) Li Wang & Mainland China: Guangxi province; W.B. Xu 07087 (PE) & GU126692 & GU126710 & GU126721 & - & GU126699 & \\
\hline Lemmaphyllum squamatum (A.R. Smith \& X.C. Zhang) Li Wang & Mainland China: Guangxi province; Zhang XC 3925 (PE) & KX891378 & KX891408 & KX891365 & - & KX891392 & - \\
\hline Lepidomicrosorium buergerianum (Miq.) Ching \& K.H. Shing & Mainland China: Sichuan province; Lu SG-QC14 (PYU) & EU363247 & EU363260 & & - & - & - \\
\hline Lepidomicrosorium buergerianum (Miq.) Ching \& K.H. Shing & Mainland China: Yunnan province; Shui $80894(\mathrm{PE})$ & GQ256315 & GQ256392 & GQ256242 & - & GQ256156 & - \\
\hline Lepidomicrosorium subhemionitideum (H.Christ) P.S.Wang & Mainland China: Yunnan province; D.Li 80 (PE) & & GU126711 & GU126722 & - & GU126700 & - \\
\hline Lepidomicrosorium subhemionitideum (H.Christ) P.S.Wang & Mainland China: Guangxi province; Zhang 4111 (PE) & GU126693 & GU126712 & GU126723 & - & GU126701 & - \\
\hline \begin{tabular}{|l} 
Lepidomicrosorium superficiale (Blume) L. Wang \\
\end{tabular} & Mainland China; Zhang XC $1290(\mathrm{PE})$ & KX891379 & KX891409 & KX891366 & - & KX891394 & - \\
\hline Lepidomicrosorium superficiale (Blume) L. Wang & Taiwan Islands; CC.Chen 1094 (H, HITBC) & MH665029 & MH665092 & MH665159 & & & \\
\hline \begin{tabular}{|l} 
Lepidomicrosorium superficiale (Blume) L. Wang \\
\end{tabular} & \begin{tabular}{|l} 
Taiwan Islands; CC.Chen 1104 (HITBC) \\
\end{tabular} & MH051159 & MH113458 & MH113492 & MH113525 & MH113558 & MH113591 \\
\hline Lepidomicrosorium superficiale (Blume) L. Wang & Taiwan Islands; Cranfill TW030 (UC) & EU482971 & EU483022 & GU126730 & & GU126708 & \\
\hline Lepidomicrosorium superficiale (Blume) L. Wang & Japan Islands; Wade 3645 (TAIF) & MH665030 & $-\infty$ & - & - & 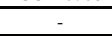 & - \\
\hline Lepidomicrosorium superficiale (Blume) L. Wang & Taiwan Islands; Cranfill TW073 (UC) & AY362568 & $\mathrm{AY} 362641$ & & & & \\
\hline Lepidomicrosorium superficiale (Blume) L. Wang & Taiwan Islands; CC.Chen 1102 (H, HITBC) & MH051158 & MH113457 & MH113491 & MH113524 & MH113557 & MH113590 \\
\hline Lepidomicrosorium superficiale (Blume) L. Wang & Indonesia Islands: Java; Wade 1913 (TAIF) & MH051160 & MH113459 & MH113493 & MH113526 & MH113559 & MH113592 \\
\hline Lepidomicrosorium superficiale (Blume) L. Wang & Mainland China: Yunnan province; SG Lu s.n. & AY725055 & AY725048 & AY725049 & (n) & - & - \\
\hline Lepidomicrosorium superficiale (Blume) L. Wang & Mainland China: Yunnan province; Kuo 2915 (TAIF) & MH051161 & MH113460 & MH113494 & MH113527 & MH113560 & MH113593 \\
\hline Lepisorus accedens (Blume) Hosok. & Philippine Islands; Kuo LY kuo2072 (TAI) & KX891368 & KX891401 & KX891354 & - & KX891382 & - \\
\hline \begin{tabular}{|l} 
Lepisorus accedens (Blume) Hosok. \\
\end{tabular} & \begin{tabular}{|l} 
Philippine Islands; FJ11-129 Schneider H (BM) \\
\end{tabular} & KX891369 & KX891400 & KX891353 & - & KX891381 & - \\
\hline Lepisorus affinis Ching & cult. SZBG; Zhang 4219 (PE) & GQ256256 & GQ256328 & GQ256173 & - & GQ256086 & - \\
\hline Lepisorus albertii (Regel) Ching & Mainland China: Xinjiang province; Zhang $4325(\mathrm{PE})$ & GQ256257 & GQ256329 & GQ256174 & - & GQ256087 & - \\
\hline Lepisorus angustus Ching & Tibetan Plateau; Shen Z.H. S25 (PE) & GQ256290 & GQ256364 & GQ256214 & - & GQ256127 & - \\
\hline Lepisorus annamensis (C.Chr.) Li Wang & Indonesia Islands: East Kalimantan; Hovenkamp 05-277 (L) & EU482931 & EU482976 & EU483025 & - & - & - \\
\hline Lepisorus annamensis (C.Chr.) Li Wang & Hainan Island; D Li 873 (PE) & GQ256252 & GQ256324 & GQ256166 & - & GQ256079 & - \\
\hline Lepisorus annuifrons (Makino) Ching & Japan Islands; Kyoto Kokubo s.n. (TI) & GQ256258 & GQ256331 & GQ256176 & - & GQ256089 & - \\
\hline Lepisorus asterolepis (Baker) Ching ex S.X. Xu & Mainland China: Sichuan province; Zhang $5171(\mathrm{PE})$ & GQ256259 & GQ256332 & GQ256177 & - & $\mathrm{GQ} 256090$ & - \\
\hline \begin{tabular}{|l} 
Lepisorus bampsii (Pic. Serm.) Zink \\
\end{tabular} & Africa Continent; R. Viane $11233(\mathrm{PE})$ & GQ256260 & GQ256333 & GQ256178 & - & GQ256091 & - \\
\hline Lepisorus bicolor (Takeda) Ching & Tibetan Plateau; Zhang 5157 (PE) & GQ256261 & GQ256334 & GQ256179 & - & GQ256092 & - \\
\hline \begin{tabular}{|l} 
Lepisorus boninensis (Christ) Ching \\
\end{tabular} & cult. TBG acc.54022 [Japan Islands] & GQ256262 & GQ256335 & GQ256180 & - & GQ256093 & - \\
\hline Lepisorus clathratus (C.B.Clarke) Ching & Mainland China: Yunnan province; Zhang 4533 (PE) & GQ256263 & GQ256336 & GQ256181 & - & GQ256110 & - \\
\hline \begin{tabular}{|l} 
Lepisorus clathratus (C.B.Clarke) Ching \\
\end{tabular} & Mainland China: Yunnan province; Zhang $4515(\mathrm{PE})$ & GQ256275 & GQ256349 & GQ256197 & - & GQ256094 & - \\
\hline Lepisorus clathratus (C.B.Clarke) Ching & Tibetan Plateau; Dickoré 12430 (GOET) & DQ642154 & DQ642192 & DQ642236 & - & 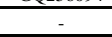 & - \\
\hline Lepisorus clathratus (C.B.Clarke) Ching & Mainland China: Beijing; jingB-1 (PE) & KY419704* & KY419704* & KY419704* & KY419704* & KY419704* & KY419704* \\
\hline \begin{tabular}{|l} 
Lepisorus confluens W.M. Chu \\
\end{tabular} & Mainland China: Yunnan province; C.D. Xu s.n. (PE) & GQ256264 & GQ256337 & GQ256182 & - & GQ256095 & - \\
\hline Lepisorus contortus (Christ) Ching & Mainland China: Shanxi province; Q.R. Liu (PE) & GQ256266 & GQ256339 & GQ256184 & & $\mathrm{GQ256098}$ & \\
\hline Lepisorus contortus (Christ) Ching & Tibetan Plateau; Zhang 4699 (PE) & GQ256308 & GQ256384 & GQ256235 & 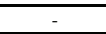 & GQ256148 & - \\
\hline Lepisorus elegans Ching ex W.M. Chu & Mainland China: Yunnan province; Zhang 4444 (PE) & GQ256268 & GQ256342 & GQ256187 & - & $\mathrm{GQ} 256100$ & - \\
\hline Lepisorus excavatus (Willd.) Ching & Africa Continent: Tanzania; Hemp 3561 (DSM) & DQ642155 & DQ642193 & GQ256189 & - & GQ256101 & - \\
\hline \begin{tabular}{|l} 
Lepisorus excavatus (Willd.) Ching \\
\end{tabular} & Grande Comore Island; Rakotondrainibe 6785 (P) & DQ642156 & DQ642194 & GQ256188 & - & GQ256102 & - \\
\hline Lepisorus hachijoensis Sa. Kurata & Japan Islands; Zhang 4358 (PE) & GQ256269 & GQ256343 & GQ256190 & - & GQ256103 & - \\
\hline Lepisorus henryi (Hieron. ex C.Chr.) Li Wang & Mainland China: Yunnan province; Shui $80679(\mathrm{PE})$ & GQ256253 & GQ256325 & GQ256167 & - & GQ256080 & - \\
\hline \begin{tabular}{|l} 
Lepisorus heterolepis (Rosenst.) Ching \\
\end{tabular} & Tibetan Plateau; Zhang 5064 (PE) & GQ256270 & GQ256344 & GQ256191 & - & GQ256104 & - \\
\hline Lepisorus hsiaowutaiensis Ching \& S.K. Wu & Mainland China: Hebei province; Q.R. Liu (PE) & GQ256271 & GQ256345 & GQ256192 & - & GQ256105 & - \\
\hline Lepisorus kawakamii (Hayata) Tagawa & Taiwan Islands; Ranker 2051 (COLO) & EU482940 & EU482990 & GQ256193 & & GQ256106 & \\
\hline Lepisorus kuchenensis (Y.C. Wu) Ching & Mainland China: Guangxi province; J.M. Xi 08188 (PE) & GQ256272 & GQ256346 & GQ256194 & - & GQ256107 & - \\
\hline Lepisorus lewisii (Baker) Ching & Mainland China: Anhui province; Y Liu 05620 (PE) & GQ256273 & GQ256347 & GQ256195 & & GQ256108 & \\
\hline Lepisorus likiangensis Ching \& S.K. Wu & Mainland China: Yunnan province; Zhang 4468 (PE) & GQ256303 & $\mathrm{GQ} 256379$ & GQ256230 & - & GQ256099 & - \\
\hline Lepisorus likiangensis Ching \& S.K. Wu & Mainland China: Yunnan province; Zhang 4488 (PE) & GQ256267 & GQ256341 & GQ256186 & - & GQ256109 & - \\
\hline Lepisorus likiangensis Ching \& S.K. Wu & Tibetan Plateau; Zhang 5117 (PE) & GQ256274 & GQ256348 2010 & GQ256196 & & GQ256143 & \\
\hline
\end{tabular}




\begin{tabular}{|c|c|c|c|c|c|c|c|}
\hline Lepisorus lineariformis Ching \& S.K. Wu & Tibetan Plateau; Zhang 4771 (PE) & GQ256276 & GQ256350 & GQ256198 & & GQ256111 & - \\
\hline Lepisorus lineariformis Ching \& S.K. Wu & Mainland China: Yunnan province; Zhang $4437(\mathrm{PE})$ & GQ256277 & GQ256351 & GQ256199 & - & GQ256112 & - \\
\hline \begin{tabular}{|l} 
Lepisorus loriformis (Wall. ex Mett.) Ching \\
\end{tabular} & Mainland China: Yunnan province; Zhang $4440(\mathrm{PE})$ & GQ256278 & GQ256352 & GQ256201 & - & GQ256114 & - \\
\hline Lepisorus loriformis var. steniste (C.B. Clarke) Ching & Tibetan Plateau; Z.D. Fang XZ-412 (PE) & GQ256279 & GQ256353 & GQ256202 & - & GQ256115 & - \\
\hline \begin{tabular}{|l} 
Lepisorus luchunensis Y.X. Lin \\
\end{tabular} & Mainland China: Yunnan province; Qi $097(\mathrm{PE})$ & $\mathrm{HQ712000}$ & HQ712008 & $\mathrm{HQ712019}$ & - & HQ712007 & - \\
\hline Lepisorus macrosphaerus (Baker) Ching & Tibetan Plateau; Zhang 4794 (PE) & GQ256280 & GQ256354 & GQ256203 & 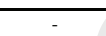 & GQ256116 & - \\
\hline Lepisorus macrosphaerus (Baker) Ching & cult. KBG; Kim 2012-3 (KUN) & JX103697 & JX103739 & JX103781 & 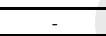 & JX103655 & - \\
\hline Lepisorus macrosphaerus (Baker) Ching & Taiwan Islands; Cranfill TW018 (UC) & EU482941 & EU482991 & EU483036 & - & - & - \\
\hline Lepisorus marginatus Ching & Mainland China: Hubei province; Zhang $3360(\mathrm{PE})$ & GQ256281 & GQ256355 & GQ256204 & - & GQ256117 & - \\
\hline Lepisorus medogensis Ching \& Y.X. Lin & Tibetan Platea; Z.D. Fang XZ-266 (PE) & GQ256282 & GQ256356 & GQ256205 & - & GQ256118 & - \\
\hline Lepisorus megasorus (C. Chr.) Ching & Taiwan Islands; Cranfill TW069 (UC) & DQ642158 & DQ642196 & GQ256206 & - & GQ256119 & 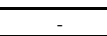 \\
\hline Lepisorus miyoshianus (Makino) Fraser-Jenk. \& Subh. Chandra & Taiwan Islands; Cranfill TW087 (UC) & AY362563 & AY362630 & $\frac{\mathrm{DQ} 179640}{1}$ & & & - \\
\hline \multirow{2}{*}{ Lepisorus miyoshianus (Makino) Fraser-Jenk. \& Subh. Chandra } & Mainland China: Sichuan province; C.C. Liu DB06104 (PE) & GQ256255 & GQ256327 & GQ256172 & & GQ256085 & - \\
\hline & Taiwan Islands; E. Schuettpelz 1136A (DUKE) & & & & KF909068 & & KF909023 \\
\hline Lepisorus monilisorus (Hayata) Tagawa & \begin{tabular}{|l} 
Taiwan Islands; Cranfill TW012 (UC) \\
\end{tabular} & EU482942 & EU482992 & EU483037 & & & - \\
\hline Lepisorus monilisorus (Hayata) Tagawa & Taiwan Islands; H.M. Zhang 20050117 (PE) & GQ256283 & GQ256357 & GQ256207 & - & GQ256120 & - \\
\hline Lepisorus morrisonensis (Hayata) H. Itô & Tibetan Plateau; Zhang $5113(\mathrm{PE})$ & GQ256284 & GQ256358 & GQ256208 & - & GQ256121 & - \\
\hline Lepisorus morrisonensis (Hayata) H. Itô & Tibetan Plateau; Zhang $4736(\mathrm{PE})$ & GQ256285 & GQ256359 & GQ256209 & - & GQ256122 & - \\
\hline \begin{tabular}{|l} 
Lepisorus mucronatus (Fée) Li Wang \\
\end{tabular} & Malaysia; Jaman 5891 (UC) & AY362562 & AY362629 & GQ256168 & - & GQ256081 & - \\
\hline \begin{tabular}{|l} 
Lepisorus obscurevenulosus (Hayata) Ching \\
\end{tabular} & Mainland China: Guangxi province; Zhang $4151(\mathrm{PE})$ & GQ256286 & GQ256360 & GQ256210 & - & GQ256123 & - \\
\hline Lepisorus oligolepidus (Baker) Ching & Tibetan Plateau; Zhang 5082 (PE) & GQ256287 & GQ256361 & GQ256211 & - & GQ256124 & - \\
\hline Lepisorus onoei (Franch. \& Sav.) Ching & Japan Islands; Zhang 4352 (PE) & GQ256288 & GQ256362 & GQ256212 & - & GQ256125 & - \\
\hline Lepisorus patungensis Ching \& S.K. Wu & Mainland China: Hubei province; Zhang $3413(\mathrm{PE})$ & GQ256289 & GQ256363 & GQ256213 & - & GQ256126 & - \\
\hline Lepisorus platyrhynchos (Kunze) Li Wang & cult. BGZ; Kreier s.n. (GOET) & DQ642152 & DQ642190 & DQ642233 & - & GQ256082 & - \\
\hline Lepisorus pseudonudus Ching & Mainland China: Sichuan province; Zhang $4249(\mathrm{PE})$ & GQ256291 & GQ256365 & GQ256215 & - & GQ256128 & - \\
\hline \begin{tabular}{|l} 
Lepisorus pseudoussuriensis Tagawa \\
\end{tabular} & Taiwan Islands; Cranfill TW093 (UC) & EU482943 & EU482993 & GQ256216 & - & GQ256129 & - \\
\hline $\begin{array}{l}\text { Lepisorus pumilus } \text { Ching \& S.K. Wu } \\
\end{array}$ & Mainland China: Gansu province; M.Z. Wang 60667 (PE) & GQ256292 & GQ256366 & GQ256217 & - & GQ256130 & - \\
\hline Lepisorus rotundus Ching & Africa Continent: Tanzania; RV 7675 & HQ711996 & HQ712012 & HQ712015 & - & $\mathrm{HQ712006}$ & - \\
\hline Lepisorus schraderi (Mett.) Ching & Reunion Island; RV 8253 & HQ711998 & HQ712010 & HQ712016 & - & HQ712002 & - \\
\hline Lepisorus scolopendrium (Ching) Mehra \& Bir & Indochina: Laos; Wu 2441 (KUN) & JX103698 & JX103740 & JX103782 & - & JX103656 & - \\
\hline Lepisorus scolopendrium (Ching) Mehra \& Bir & Tibetan Plateau; Zhang 4659 (PE) & GQ256294 & GQ256368 & GQ256219 & - & GQ256133 & - \\
\hline \begin{tabular}{|l} 
Lepisorus scolopendrium (Ching) Mehra \& Bir \\
\end{tabular} & Tibetan Plateau; Y.D. Tang YD-076 (PE) & GQ256295 & GQ256369 & GQ256220 & 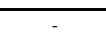 & GQ256132 & - \\
\hline Lepisorus sinensis (Christ) Ching & Mainland China: Yunnan province; Shui 81069 (PE) & GQ256296 & GQ256370 & GQ256221 & - & GQ256134 & - \\
\hline Lepisorus sordidus (C. Chr.) Ching & Mainland China: Yunnan province; Zhang $3218(\mathrm{PE})$ & GQ256298 & GQ256372 & GQ256223 & - & GQ256135 & \\
\hline \begin{tabular}{|l} 
Lepisorus sordidus (C. Chr.) Ching \\
\end{tabular} & Mainland China: Sichuan province; Zhang 0612(PE) & GQ256297 & GQ256371 & GQ256222 & - & GQ256136 & - \\
\hline \multirow{2}{*}{ Lepisorus spicatus (L.f.) Li Wang } & cult. BGG; Schneider s.n. (GOET) & DQ642153 & DQ642191 & DQ642234 & & & - \\
\hline & Tahiti Island; Ranker 1915 (COLO) & - & र्य & - & EF463800 & EF463490 & - \\
\hline Lepisorus subconfluens Ching & Mainland China: Yunnan province; Zhang $4518(\mathrm{PE})$ & GQ256299 & GQ256373 & GQ256224 & - & GQ256137 & - \\
\hline Lepisorus sublinearis (Baker ex Takeda) Ching & Mainland China: Yunnan province; Shui 80595 (PE) & GQ256300 & GQ256374 & GQ256225 & - & GQ256139 & - \\
\hline \begin{tabular}{|l} 
Lepisorus sublinearis (Baker ex Takeda) Ching \\
\end{tabular} & Mainland China: Yunnan province; Shui $81060(\mathrm{PE})$ & $\mathrm{GQ256301}$ & $\mathrm{GQ256375}$ & GQ256226 & - & $\mathrm{GQ256138}$ & 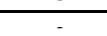 \\
\hline Lepisorus thaipaiensis Ching \& S.K. Wu & Mainland China: Shanxi province; G.Y. Rao 2005-045A (PE) & GQ256302 & GQ256378 & GQ256229 & - & GQ256142 & - \\
\hline Lepisorus thunbergianus (Kaulf.) Ching & Mainland China: Chongqing; Zhang 5205 (PE) & GQ256305 & GQ256381 & GQ256232 & - & GQ256144 & - \\
\hline Lepisorus thunbergianus (Kaulf.) Ching & Mainland China: Yunnan province; Zhang 4544 (PE) & GQ256306 & GQ256382 & GQ256233 & - & GQ256146 & - \\
\hline $\begin{array}{l}\text { Lepisorus thunbergianus (Kaulf.) Ching } \\
\end{array}$ & Japan Islands; Koichi Ohora 2005042404 (TI) & GQ256304 & GQ256380 & GQ256231 & 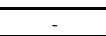 & GQ256145 & - \\
\hline \begin{tabular}{|l} 
Lepisorus tibeticus Ching \& S.K. Wu \\
\end{tabular} & Tibetan Plateau; Zhang 4694 (PE) & GQ256307 & GQ256383 & GQ256234 & - & GQ256147 & - \\
\hline Lepisorus tosaensis (Makino) H. Itô & Japan Islands; Sayumi Fujimoto 2005042904 (TI) & GQ256309 & GQ256385 & GQ256236 & - & GQ256149 & - \\
\hline Lepisorus uchiyamae (Makino) H. Itô & Japan Islands; Sayumi Fujimoto 2005042902 (TI) & GQ256310 & GQ256386 & GQ256237 & - & GQ256150 & - \\
\hline Lepisorus ussuriensis (Regel \& Maack) Ching & Mainland China: Heilongijang province; B.D. Liu s.n. (PE) & GQ256311 & GQ256387 & GQ256238 & - & GQ256151 & - \\
\hline \begin{tabular}{|l} 
Lepisorus ussuriensis var. distans (Makino) Tagawa \\
\end{tabular} & Jappan Islands; Sayumi Fujimoto SF05051602 (TI) & GQ256312 & GQ256388 & GQ256239 & - & GQ256152 & - \\
\hline Lepisorus validinervis (Kunze) Li Wang & Borneo Island; Daniele Cicuzza 2205 (UBDH) & MH665031 & MH665093 & MH665160 & MH664989 & MH665005 & MH665019 \\
\hline Lepisorus xiphiopteris (Baker) W.M. Chu ex Y.X. Lin & Mainland China: Yunnan province; C.D. Xu A0303 (PE) & GQ256313 & GQ256389 & $\overline{\text { GQ256240 }}$ & & GQ256153 & \\
\hline
\end{tabular}




\begin{tabular}{|c|c|c|c|c|c|c|c|}
\hline Leptochilus axillaris (Cav.) Kaulf. & Indochina: Laos; Wu 2344 (KUN) & JX103699 & JX103741 & JX103783 & - & JX103657 & - \\
\hline \begin{tabular}{|l} 
Leptochilus axillaris (Cav.) Kaulf. \\
\end{tabular} & Indochina: Laos; Wu 2439 (KUN) & JX103700 & JX103742 & JX103784 & 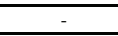 & JX103658 & \\
\hline \begin{tabular}{|l} 
Leptochilus axillaris (Cav.) Kaulf. \\
\end{tabular} & Indochina: Laos; Wu 2462 (KUN) & JX103701 & $\mathrm{JX103743}$ & JX103785 & - & JX103659 & - \\
\hline \begin{tabular}{|l} 
Leptochilus cantoniensis (Baker) Ching \\
\end{tabular} & Mainland China; Dong 743 (PE) & EU482946 & EU482996 & EU483042 & - & & - \\
\hline Leptochilus cantoniensis (Baker) Ching & Mainland China; Dong $172(\mathrm{PE})$ & EU482945 & EU482995 & EU483041 & - & - & - \\
\hline \begin{tabular}{|l} 
Leptochilus cantoniensis (Baker) Ching \\
\end{tabular} & cult. KBCC K032796 [Hainan Island]; (H) & MH665032 & MH665094 & MH665161 & - & - & - \\
\hline Leptochilus cantoniensis (Baker) Ching & Hainan Island; Kuo 1701 (TAIF) & - & MH665095 & MH665162 & - & - & - \\
\hline Leptochilus cf. decurrens & Mainland China: Yunnan province; RBGE 19933707 (PE) & MH665033 & MH665096 & MH665163 & 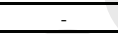 & - & - \\
\hline \multirow{2}{*}{ Leptochilus decurrens Blume } & Indonesia Islands: Java; Douglas 28 (UC) & AY096203 & AY096228 & DQ179640 & - & - & 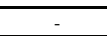 \\
\hline & cult. KBG; X.Y.Du 1003 (KUN) & 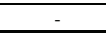 & - & - & - & HQ597027 & - \\
\hline Leptochilus decurrens Blume & cult. KBG; Kim 2012-12 (KUN) & JX103724 & JX103766 & JX103808 & - & JX103682 & 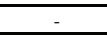 \\
\hline \begin{tabular}{|l|} 
Leptochilus digitatus (Baker) Noot. \\
\end{tabular} & Mainland China; Zhang $3509(\mathrm{PE})$ & EU482947 & $\begin{array}{ll}\text { EU482997 } \\
\end{array}$ & EU483043 & - & - & - \\
\hline Leptochilus digitatus (Baker) Noot. & Indochina: Vietnam; A.R. Smith 00-036 (UC) & EU482948 & EU482998 & EU483044 & & - & - \\
\hline $\begin{array}{l}\text { Leptochilus digitatus (Baker) Noot. } \\
\end{array}$ & Indochina: Vietnam; Chao 1556 (TAIF) & MH665034 & MH665097 & MH665164 & - & - & - \\
\hline $\begin{array}{l}\text { Leptochilus digitatus (Baker) Noot. } \\
\text { (a) }\end{array}$ & Hainan Island; Kuo 1771 (TAIF) & & MH665098 & MH665165 & - & - & - \\
\hline \begin{tabular}{|l} 
Leptochilus digitatus (Baker) Noot. \\
\end{tabular} & cult. KBCC K020955 [Indochina: Vietnam]; (H) & MH665035 & MH665099 & MH665166 & - & - & - \\
\hline $\begin{array}{l}\text { Leptochilus digitatus (Baker) Noot. } \\
\end{array}$ & Indochina: Laos; Wu 2515 (KUN) & JX103695 & JX103737 & JX103779 & - & JX103653 & - \\
\hline $\begin{array}{l}\text { Leptochilus digitatus (Baker) Noot. } \\
\end{array}$ & cult. XTBG; CC.Chen 1067 (H) & MH051162 & MH113461 & MH113495 & MH113528 & MH113561 & MH113594 \\
\hline \begin{tabular}{|l} 
Leptochilus ellipticus (Thunb. ex Murray) Noot. \\
\end{tabular} & Mainland China: Yunnan province; Lin GX 003 (PE) & MH665036 & MH665100 & MH665167 & - & - & 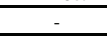 \\
\hline \begin{tabular}{|l} 
Leptochilus ellipticus (Thunb. ex Murray) Noot. \\
\end{tabular} & Japan Islands; Wade 3656 (TAIF) & MH665037 & MH665101 & MH665168 & - & - & - \\
\hline \begin{tabular}{|l} 
Leptochilus ellipticus (Thunb. ex Murray) Noot. \\
\end{tabular} & Mainland China; Zhang $1923(\mathrm{PE})$ & EU482949 & EU482999 & EU483045 & - & - & - \\
\hline Leptochilus cf. ellipticus & cult. XTBG; CC.Chen 1065 (H) & MH665038 & MH665102 & MH665169 & 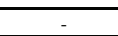 & - & \\
\hline Leptochilus ef. ellipticus & Mainland China: Yunnan province; Schneider 2011 V191 (PE) & MH665039 & MH665103 & MH665170 & - & - & - \\
\hline Leptochilus cf. ellipticus & Mainland China: Yunnan province; Schneider 2011 V013 (PE) & $\begin{array}{l}\text { MH665040 } \\
\end{array}$ & MH665104 & MH665171 & 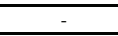 & - & 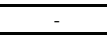 \\
\hline Leptochilus cf. ellipticus & cult. XTBG; CC.Chen $1068(\mathrm{H})$ & MH665041 & MH665105 & MH665172 & - & - & - \\
\hline Leptochilus ellipticus var. flexilobus (Christ) X.C. Zhang & Mainland China: Guangxi province; Wade 2518 (TAIF) & MH665042 & MH665106 & MH665173 & - & - & - \\
\hline Leptochilus ellipticus var. flexilobus (Christ) X.C. Zhang & cult. KBCC K032967 [Hainan Island]; (H) & & MH665107 & MH665174 & - & - & - \\
\hline Leptochilus ellipticus var. pentaphyllus (Baker) X.C. Zhang \& & Mainland China: Yunnan province; Xu A0357 (PE) & MH665043 & MH665108 & MH665175 & - & - & - \\
\hline Leptochilus ellipticus var. pentaphyllus (Baker) X.C. Zhang \& & Mainland China: Yunnan province, Ruili; SG Lu-SG9 (PYU) & EU363242 & EU363255 & - & $e_{2}$ & - & - \\
\hline \begin{tabular}{|l} 
Leptochilus hemionitideus (C. Pres) Noot. \\
\end{tabular} & cult. XTBG; CC.Chen $1066(\mathrm{H})$ & MH051165 & MH113464 & MH175521 & MH113531 & MH113564 & MH113597 \\
\hline Leptochilus hemionitideus (C. Pres) Noot. & Indochina: Laos; Wu 2437 (KUN) & JX103694 & JX103736 & JX103778 & & JX103652 & 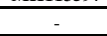 \\
\hline Leptochilus hemionitideus (C. Presl) Noot. & Taiwan Islands; CC.Chen $1015(\mathrm{H})$ & MH051164 & MH113463 & MH113497 & MH113530 & MH113563 & MH113596 \\
\hline $\begin{array}{l}\text { Leptochilus } \mathrm{x} \text { hemitomus (Hance) Noot. } \\
\end{array}$ & Mainland China; Zhang $3302(\mathrm{PE})$ & EU482951 & EU483001 & EU483047 & & & \\
\hline Leptochilus henryi (Baker) X.C. Zhang & Mainland China: Sichuan province; Zhang 2541 (PE)-1 & EU482952 & EU483002 & EU483048 & 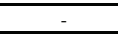 & GU126709 & - \\
\hline Leptochilus henryi (Baker) X.C. Zhang & Mainland China: Sichuan province; Zhang 2541 (PE)-2 & GQ256254 & GQ256326 & GQ256171 & - & GQ256084 & - \\
\hline Leptochilus henryi (Baker) X.C. Zhang & cult. XTBG; CC.Chen $1072(\mathrm{H})$ & MH665044 & MH665109 & MH665176 & - & - & - \\
\hline Leptochilus heterophyllus (S.K. Wu \& K.L. Phan) Christenh. & Indochina: Vietnam; WP-135 (KUN) & JX103688 & JX103730 & JX103772 & & JX103646 & - \\
\hline Leptochilus heterophyllus (S.K. Wu \& K.L. Phan) Christenh. & Indochina: Vietnam; WP-136 (KUN) & $\mathrm{JX520933}$ & JX520935 & JX520937 & ב & JX520931 & - \\
\hline Leptochilus heterophyllus (S.K. Wu \& K.L. Phan) Christenh. & Indochina: Vietnam; WP-201 (KUN) & JX520934 & JX520936 & JX520938 & - & $\begin{array}{l}\text { JX520932 } \\
\end{array}$ & - \\
\hline Leptochilus heterophyllus (S.K. Wu \& K.L. Phan) Christenh. & Mainland China: Yunnan province; P.11226 B (PE) & MH665045 & MH665110 & MH665177 & - & . & - \\
\hline Leptochilus heterophyllus (S.K. Wu \& K.L. Phan) Christenh. & Mainland China: Yunnan province; P.11226 A (PE) & MH665046 & MH665111 & MH665178 & - & - & - \\
\hline \begin{tabular}{|l} 
Leptochilus leveillei (Christ) X.C. Zhang \& Noot. \\
\end{tabular} & Mainland China: Sicuan province, Mt. Emei; SG Lu-EM26 (PYU) & EU363240 & EU363254 & - & - & - & - \\
\hline \begin{tabular}{|l} 
Leptochilus leveillei (Christ) X.C. Zhang \& Noot. \\
\end{tabular} & Mainland China: Yunnan province; Zhang 4312 (PE) & MH665047 & MH665112 & MH665179 & - & - & - \\
\hline \begin{tabular}{|l|} 
Leptochilus cf. leveillei \\
\end{tabular} & cult. XTBG; CC.Chen $1070(\mathrm{H})$ & MH051166 & MH113465 & MH113498 & MH113532 & MH113565 & MH113598 \\
\hline Leptochilus longipes (Ching) X.C. Zhang & Indochina: Vietnam; Wade 2615 (TAIF) & MH665048 & MH665113 & MH665180 & 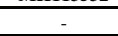 & - & - \\
\hline \begin{tabular}{|l} 
Leptochilus longipes (Ching) X.C. Zhang \\
\end{tabular} & Indochina: Vietnam; Wade 4102 (TAIF) & MH665049 & MH665114 & MH665181 & - & - & - \\
\hline $\begin{array}{l}\text { Leptochilus longipes (Ching) X.C. Zhang } \\
\end{array}$ & Mainland China: Guangxi province; Wade 2517 (TAIF) & MH665050 & MH665115 & MH665182 & - & - & - \\
\hline Leptochilus macrophyllus (Blume) Noot. & Indonesia Islands: Java; Wade 1962 (TAIF) & MH051167 & MH113466 & MH113499 & MH113533 & MH113566 & MH113599 \\
\hline Leptochilus macrophyllus (Blume) Noot. & Philippine Islands; Wade 3798 (TAIF) & & MH665116 & MH665183 & 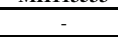 & - & 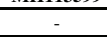 \\
\hline \begin{tabular}{|l} 
Leptochilus macrophyllus (Blume) Noot. \\
\end{tabular} & Solomon Islands; Wade 2776 (TAIF) & MH665051 & MH665117 & MH665184 & - & - & - \\
\hline Leptochilus macrophyllus (Blume) Noot. & Solomon Islands; Wade 2845 (TAIF) & MH665052 & MH665118 & MH665185 & & & \\
\hline
\end{tabular}




\begin{tabular}{|c|c|c|c|c|c|c|c|}
\hline Leptochilus pedunculatus (Hook. \& Grev.) Fraser-Jenk. & Indochina: Vietnam; Wade 1334 (TAIF) & MH051168 & MH113467 & MH113500 & MH113534 & MH113567 & MH113600 \\
\hline Leptochilus pothifolius (Buch.-Ham. ex D. Don) Fraser-Jenk. & Japan Islands; Wade 3681 (TAIF) & MH665053 & MH665119 & MH665186 & & & \\
\hline Leptochilus pothifolius (Buch.-Ham. ex D. Don) Fraser-Jenk. & Taiwan Islands; CC.Chen $1017(\mathrm{H})$ & MH051163 & MH113462 & MH113496 & MH113529 & MH113562 & MH113595 \\
\hline Leptochilus pothifolius (Buch.-Ham. ex D. Don) Fraser-Jenk. & Mainland China: Yunnan province; Zhang $4231(\mathrm{PE})$ & MH665054 & MH665120 & MH665187 & 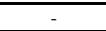 & & - \\
\hline \begin{tabular}{|l} 
Leptochilus pothifolius (Buch.-Ham. ex D. Don) Fraser-Jenk. \\
\end{tabular} & Mainland China: Yunnan province; Zhang 4207 (PE) & MH665055 & MH665121 & MH665188 & - & - & - \\
\hline Leptochilus pothifolius (Buch.-Ham. ex D. Don) Fraser-Jenk. & Mainland China: Guangxi province; Wade 2519 (TAIF) & MH665056 & MH665122 & MH665189 & - & - & - \\
\hline Leptochilus pothifolius (Buch.-Ham. ex D. Don) Fraser-Jenk. & Indochina: Laos; Wu 2712 (KUN) & JX103696 & JX103738 & JX103780 & - & JX103654 & - \\
\hline Leptochilus ef. pothifolius & Mainland China: Yunnan province; Zhang 4356 (PE) & MH665057 & MH665123 & MH665190 & - & & - \\
\hline Leptochilus cf. pothifolius & Mainland China: Yunnan province; CC.Chen 1112 (HITBC) & MH665058 & MH665124 & MH665191 & MH664990 & MH665006 & \\
\hline Leptochilus cf. pothifolius & Mainland China: Yunnan province; CC.Chen 1113 (HITBC) & MH665059 & MH665125 & MH665192 & MH664991 & MH665007 & MH665020 \\
\hline Leptochilus pteropus (Blume) Fraser-Jenk. & cult. BGG; Kreier s.n. (GOET) & EU482965 & EU483016 & EU483061 & & & \\
\hline Leptochilus pteropus (Blume) Fraser-Jenk. & Mainland China: Yunnan province; Zhang $4225(\mathrm{PE})$ & MH665060 & MH665126 & MH665193 & & & \\
\hline Leptochilus pteropus (Blume) Fraser-Jenk. & Taiwan Islands; CC.Chen $1010(\mathrm{H})$ & MH051176 & MH113475 & MH113508 & MH113542 & MH113575 & MH113608 \\
\hline Leptochilus $\mathrm{X}$ shintenensis (Hayata) X.C. Zhang \& Noot. & \begin{tabular}{|l} 
cult. KBCC K017274 [Taiwan Islands] \\
\end{tabular} & MH051169 & MH113468 & MH113501 & MH113535 & MH113568 & MH113601 \\
\hline Leptochilus simplifrons (H. Christ) Tagawa & cult. JNU; Zhang 3800 (PE) & EU482953 & EU483003 & EU483049 & & & \\
\hline \multirow{2}{*}{ Leptochilus wrightii (Hook. \& Baker) X.C. Zhang } & cult. KBG; Kim 2012-15 (KUN) & JX103727 & JX103769 & JX103811 & - & JX103685 & - \\
\hline & Taiwan Islands; Li 596 (TAIF) & & & & JF304021 & & $\mathrm{JF} 303959$ \\
\hline Leptochilus wrightii (Hook. \& Baker) X.C. Zhang & Taiwan Islands; CC.Chen 1087 (H) & MH051170 & MH113469 & MH113502 & MH113536 & MH113569 & MH113602 \\
\hline Leptochilus wrightii (Hook. \& Baker) X.C. Zhang & cult. KBCC K015603 [Taiwan Islands]; (H) & MH665061 & MH665127 & MH665194 & (1) & - & 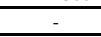 \\
\hline Leptochilus wrightii (Hook. \& Baker) X.C. Zhang & Japan Islands; Tsutsumi 1067 (CT) & EU482954 & EU483004 & EU483050 & - & - & - \\
\hline Leptochilus wrightii (Hook. \& Baker) X.C. Zhang & Taiwan Islands; CC.Chen $1016(\mathrm{H})$ & MH665062 & MH665128 & MH665195 & - & - & - \\
\hline Leptochilus wrightii (Hook. \& Baker) X.C. Zhang & cult. KBCC K015605 [Taiwan Islands]; (H) & MH665063 & MH665129 & MH665196 & - & - & - \\
\hline Leptochilus wrightii (Hook. \& Baker) X.C. Zhang & Mainland China: Yunnan province; Li $47(\mathrm{PE})$ & MH665064 & MH665130 & MH665197 & - & - & - \\
\hline Leptochilus cf. wrightii & Mainland China: Yunnan province; Schneider 2011 V163 (PE) & MH665065 & MH665131 & MH665198 & - & - & - \\
\hline Leptochilus sp. & Japan Islands; Wade 3657 (TAIF) & MH665066 & MH665132 & MH665199 & - & - & - \\
\hline \begin{tabular}{|l} 
Leptochilus sp. \\
\end{tabular} & cult. XTBG; CC.Chen $1071(\mathrm{H})$ & MH665067 & MH665133 & MH665200 & - & 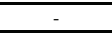 & \\
\hline Microsorum biseriatum (Bosman) Noot. & Solomon Islands; Wade 2735 (TAIF) & MH051189 & MH113488 & MH113521 & MH113554 & MH113587 & MH113621 \\
\hline \begin{tabular}{|l} 
Microsorum commutatum (Bl.) Copel. \\
\end{tabular} & Solomon Islands; Wade 2810 (TAIF) & MH665068 & MH665134 & MH665201 & - & - & - \\
\hline \multirow{2}{*}{ Microsorum commutatum (Bl.) Copel. } & Admiralty Islands, Wagner \& Grether 3481 (UC) & AY362571 & & & - & - & - \\
\hline & cult. Whitehead; A.R. Smith 2901 (UC) & & EU483005 & EU483051 & - & - & - \\
\hline \begin{tabular}{|l} 
Microsorum commutatum (Bl.) Copel. \\
\end{tabular} & \begin{tabular}{|l|l|} 
Philippine Islands; Wade 3768 (TAIF) \\
\end{tabular} & MH051171 & MH113470 & MH113503 & MH113537 & MH113570 & MH113603 \\
\hline \multirow{3}{*}{ Microsorum cuspidatum (D. Don) Tagawa } & cult. LBG 3560 & AF470335 & & AY083638 & - & - & - \\
\hline & cult. source (UC) & - & AY096230 & & - & - & - \\
\hline & cult. KBG; X.Y.Du 1002 (KUN) & - & - & - & - & HQ597026 & - \\
\hline Microsorum cuspidatum (D. Don) Tagawa & cult. KBG; Kim 2012-14 (KUN) & JX103726 & JX103768 & JX103810 & - & JX103684 & - \\
\hline Microsorum cuspidatum (D. Don) Tagawa & cult. KBG; Kim 2012-6 (KUN) & JX103707 & JX103749 & JX103791 & - & JX103665 & - \\
\hline Phymatosorus cuspidatus $[=$ M. cuspidatum $]$ subsp. beddomei & South of Indian subcontinent; FN132 (TAIF) & MH665069 & MH665135 & MH665202 & MH664992 & & \\
\hline Microsorum glossophyllum Copel. & Solomon Islands; Wade 2782 (TAIF) & MH051179 & MH113478 & MH113511 & MH113545 & MH113578 & MH113611 \\
\hline \begin{tabular}{|l} 
Microsorum glossophyllum Copel. \\
\end{tabular} & Solomon Islands; Wade 3053 (TAIF) & MH051180 & MH113479 & MH113512 & MH175522 & MH113579 & MH113612 \\
\hline Microsorum grossum (Langsd. \& Fisch.) S.B. Andrews & Solomon Islands; Wade 2910 (TAIF) & MH665070 & MH665136 & MH665203 & & & \\
\hline \multirow{2}{*}{ Microsorum grossum (Langsd. \& Fisch.) S.B. Andrews } & Hawaiian Islands; Lorence 9155 (DL) & EU482956 & EU483007 & EU483053 & - & - & - \\
\hline & Moorea Island; Ranker 1941(COLO) & - & - & - & EF463831 & EF463500 & - \\
\hline Microsorum grossum (Langsd. \& Fisch.) S.B. Andrews & Moorea Island; Ranker 1941(COLO) & DQ179633 & DQ179636 & DQ179642 & - & - & - \\
\hline Microsorum hainanense Noot. & Hainan Island; Lu SG-V73 (PYU) & EU363249 & EU363263 & 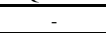 & - & - & - \\
\hline Microsorum heterocarpum Ching & Philippine Islands; Wade 3758 (TAIF) & MH665071 & MH665137 & - & - & - & - \\
\hline Microsorum heterocarpum Ching & Borneo Island; Daniele Cicuzza 2203 (UBDH) & MH665072 & MH665138 & MH665204 & MH664993 & MH665008 & MH665021 \\
\hline Microsorum insigne (Blume) Copel. & Indonesia Islands: Java; Wade 2059 (TAIF) & MH665073 & MH665139 & MH665205 & - & - & - \\
\hline \begin{tabular}{|l} 
Microsorum insigne (Blume) Copel. \\
\end{tabular} & Indochina: Laos; Wu 2435 (KUN) & JX103703 & JX103745 & JX103787 & & JX103661 & \\
\hline Microsorum insigne (Blume) Copel. & Mainland China: Yunnan province; CC.Chen 1116 (HITBC) & MH665074 & MH665140 & MH665206 & MH664994 & MH665009 & \\
\hline \begin{tabular}{|l} 
Microsorum insigne (Blume) Copel. \\
(B.
\end{tabular} & Indochina: Thailand; Lu.P.F. 15695 (TAIF) & MH051173 & MH113472 & MH113505 & MH113539 & MH113572 & MH113605 \\
\hline Microsorum insigne (Blume) Copel. & Indochina: Vietnam; WadeVN 072 (TAIF) & MH665075 & MH665141 & MH665207 & & & \\
\hline
\end{tabular}




\begin{tabular}{|c|c|c|c|c|c|c|c|}
\hline Microsorum insigne (Blume) Copel. & Mainland China: Yunnan province; CC.Chen 1109 (HITBC) & MH665076 & MH665142 & MH665208 & MH664995 & MH665010 & MH665022 \\
\hline \begin{tabular}{|l} 
Microsorum insigne (Blume) Copel. \\
\end{tabular} & cult. XTBG; CC.Chen $1073(\mathrm{H})$ & MH051172 & MH113471 & MH113504 & MH113538 & MH113571 & MH113604 \\
\hline \begin{tabular}{|l} 
Microsorum insigne (Blume) Copel. \\
\end{tabular} & Mainland China; Liu 204 (PE) & EU482957 & EU483008 & EU483054 & - & - & - \\
\hline \begin{tabular}{|l} 
Microsorum insigne (Blume) Copel. \\
\end{tabular} & Mainland China; Liu 214 (PE) & EU482958 & EU483009 & EU483055 & & & - \\
\hline \begin{tabular}{|l} 
Microsorum insigne (Blume) Copel. \\
\end{tabular} & Mainland China; Zhang $3510(\mathrm{PE})$ & EU482959 & EU483010 & EU483056 & - & - & - \\
\hline Microsorum lastii (Baker) Tardieu & Perier $7937(\mathrm{P})$ & EU482961 & EU483012 & EU483058 & - & - & - \\
\hline \begin{tabular}{|l} 
Microsorum linguiforme (Mett.) Copel. \\
\end{tabular} & New Guinea Island; T. Ranker 1776 (UC) & AF470334 & - & AY083637 & - & - & - \\
\hline \begin{tabular}{|l} 
Microsorum linguiforme (Mett.) Copel. \\
\end{tabular} & Solomon Islands; Wade 2887 (TAIF) & MH051174 & MH113473 & MH113506 & MH113540 & MH113573 & MH113606 \\
\hline Microsorum membranaceum (D.Don) Ching var. membranaceum & cult. Xishuanbanna; Li $95(\mathrm{PE})$ & EU482962 & EU483013 & EU483059 & & - & - \\
\hline Microsorum membranaceum (D.Don) Ching var. membranaceum & Taiwan Islands; Cranfill TW042 (UC) & EU482963 & DQ642199 & DQ642244 & - & & - \\
\hline Microsorum membranaceum (D.Don) Ching var. membranaceum & Taiwan Islands; CC.Chen 1077 (H) & MH051175 & MH113474 & MH113507 & MH113541 & MH113574 & MH113607 \\
\hline Microsorum membranaceum (D.Don) Ching var. membranaceum & cult. KBG; Kim 2012-2 (KUN) & JX103704 & JX103746 & JX103788 & & JX103662 & - \\
\hline \multirow{2}{*}{ Microsorum membranaceum (D.Don) Ching var. membranaceum } & Mainland China: Yunnan province; SG Lu s.n. & AY725053 & AY725047 & AY725051 & & & - \\
\hline & Mainland China: Yunnan province; Shui YM et al. 80767 & - & - & & - & KX891393 & - \\
\hline Microsorum membranaceum var. carinatum W.M.Chu \& Z.R.He & Mainland China: Yunnan province; SG Lu s.n. & AY725054 & AY725046 & AY725050 & & & \\
\hline \begin{tabular}{|l} 
Microsorum membranifolium (R. Br.) Ching \\
\end{tabular} & Solomon Islands; Wade 2753 (TAIF) & MH665077 & MH665143 & MH665209 & MH664996 & MH665011 & MH665023 \\
\hline \begin{tabular}{|l} 
Microsorum membranifolium (R. Br.) Ching \\
\end{tabular} & Hawaiian Islands; Dunn 458 (LOA) & EU482964 & EU483014 & EU483060 & & & \\
\hline Microsorum membranifolium (R. Br.) Ching & cult. CBG; Wade 1824 (TAIF) & MH665078 & MH665144 & MH665210 & MH664997 & MH665012 & MH665024 \\
\hline Microsorum membranifolium (R. Br.) Ching & cult. BGG; Schneider s.n. (GOET) & DQ642161 & DQ642200 & DQ642245 & - & - & - \\
\hline $\begin{array}{l}\text { Microsorum musifolium (Blume) Copel. } \\
\end{array}$ & cult. UCBG 58.0649 [Indonesia Islands: Java; (UC)] & AF470333 & & AY083636 & & & - \\
\hline \begin{tabular}{|l} 
Microsorum musifolium (Blume) Copel. \\
\end{tabular} & cult. KBCC K013621[Indochina: Thailand]; (H) & MH665079 & MH665145 & MH665211 & MH664998 & MH665013 & - \\
\hline Microsorum musifolium (Blume) Copel. & cult. KBCC K013966 [Taiwan Islands]; (H) & MH665080 & MH665146 & MH665212 & MH664999 & & \\
\hline $\begin{array}{l}\text { Microsorum novae-zealandiae (Baker) Copel. } \\
\text {. }\end{array}$ & New Zealand Islands; Perrie et al. (WELT P20873) & DQ401116 & DQ401126 & DQ401121 & - & - & - \\
\hline 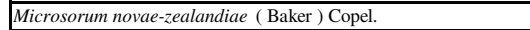 & New Zealand Islands (WELT P20876; LRP3584) & DQ401120 & & DQ401124 & - & & - \\
\hline \begin{tabular}{|l} 
Microsorum papuanum (Baker) Parris \\
\end{tabular} & cult. BGB; Schuettpelz 603 (GOET) & DQ642162 & EU483015 & DQ642246 & - & - & - \\
\hline Microsorum powellii (Hook. \& Baker) Copel. & Solomon Islands; Wade 3352 (TAIF) & MH665081 & MH665147 & MH665213 & MH665000 & MH665014 & MH665025 \\
\hline Microsorum cf. punctatum & cult. BGH, Schneider s.n. (GOET) & DQ164444 & DQ164475 & DQ164508 & & & \\
\hline \begin{tabular}{|l} 
Microsorum punctatum (L.) Copel. \\
\end{tabular} & Taiwan Islands; CC.Chen $1076(\mathrm{H})$ & MH051178 & MH113477 & MH113510 & MH113544 & MH113577 & MH113610 \\
\hline \begin{tabular}{|l} 
Microsorum punctatum (L.) Copel. \\
\end{tabular} & Indochina: Laos; Wu 2506 (KUN) & JX103705 & JX103747 & JX103789 & & JX103663 & \\
\hline \begin{tabular}{|l} 
Microsorum punctatum (L.) Copel. \\
\end{tabular} & Indochina: Vietnam; Wade 1390 (TAIF) & MH051177 & MH113476 & MH113509 & MH113543 & MH113576 & MH113609 \\
\hline Microsorum punctatum (L.) Copel. & Hainan Island; Zhang 4194 (PE) & GQ256316 & GQ256394 & GQ256244 & 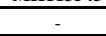 & GQ256158 & - \\
\hline \begin{tabular}{|l} 
Microsorum punctatum (L.) Copel. \\
\end{tabular} & cult. LBG 24091 [Philippine Islands; C. Ridsdale] & AF470337 & & AY083640 & - & - & - \\
\hline Microsorum punctatum (L.) Copel. & Taiwan Islands; Ranker 2096 (COLO) & EU482966 & EU483017 & EU483063 & - & - & - \\
\hline $\begin{array}{l}\text { Microsorum punctatum (L.) Copel. } \\
\end{array}$ & cult. RBGV; CC.Chen $1084(\mathrm{H})$ & MH665082 & MH665148 & & - & - & - \\
\hline Microsorum pustulatum (G.Forst.) Copel. & New Zealand Islands; Perrie (WELT P20874) & DQ401117 & DQ401127 & DQ401122 & & & \\
\hline $\begin{array}{l}\text { Microsorum pustulatum (G.Forst.) Copel. } \\
\end{array}$ & Mainland Australia: Victoria; CC.Chen $1081(\mathrm{H})$ & MH051181 & MH113480 & MH113513 & MH113546 & MH113580 & MH113613 \\
\hline \begin{tabular}{|l} 
Microsorum pustulatum (G.Forst.) Copel. \\
\end{tabular} & cult. RBGV; CC.Chen $1082(\mathrm{H})$ & MH665083 & MH665149 & & 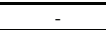 & & 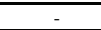 \\
\hline \begin{tabular}{|l} 
Microsorum rubidum (Kunze) Copel. \\
\end{tabular} & cult. KBCC K034174 [Malay Peninsula]; (H) & MH665084 & MH665150 & MH665214 & - & - & - \\
\hline \begin{tabular}{|l} 
Microsorum rubidum (Kunze) Copel. \\
\end{tabular} & Taiwan Islands; CC.Chen $1008(\mathrm{H})$ & MH665085 & MH665151 & MH665215 & MH665001 & MH665015 & MH665026 \\
\hline \begin{tabular}{|l} 
Microsorum rubidum (Kunze) Copel. \\
.
\end{tabular} & Indonesia Islands: Java; Wade 1931 (TAIF) & MH665086 & MH665152 & MH665216 & & -7 & - \\
\hline \begin{tabular}{|l} 
Microsorum scandens (G.Forst.) Tindale \\
\end{tabular} & cult. BGG, Kreier s.n. (GOET) & DQ212057 & DQ212058 & DQ179641 & - & - & - \\
\hline \begin{tabular}{|l} 
Microsorum scandens (G.Forst.) Tindale \\
\end{tabular} & New Zealand Islands; Perrie et al. (WELT P20875) & DQ401118 & DQ401128 & DQ401123 & - & - & - \\
\hline Microsorum scandens (G.Forst.) Tindale & Mainland Australia: Victoria; CC.Chen $1080(\mathrm{H})$ & MH051182 & MH113481 & MH113514 & MH113547 & MH113581 & MH113614 \\
\hline 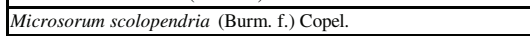 & Taiwan Islands; CC.Chen $1085(\mathrm{H})$ & MH051190 & MH113489 & MH113522 & MH113555 & MH113588 & MH113622 \\
\hline Microsorum scolopendria (Burm. f.) Copel. & Taiwan Islands; CC.Chen 1009 (H) & MH665087 & MH665153 & MH665217 & & & - \\
\hline \begin{tabular}{|l} 
Microsorum scolopendria (Burm. f.) Copel. \\
\end{tabular} & cult. BGG; Schneider s.n. (GOET) & DQ642163 & DQ642201 & DQ642247 & - & - & - \\
\hline Microsorum scolopendria (Burm. f.) Copel. & Mayotte Island; Rakotondrainibe et al. 6601 (P)-1 & DQ642164 & DQ642202 & DQ642248 & - & - & - \\
\hline Microsorum scolopendria (Burm. f.) Copel. & Mayotte Island; Rakotondrainibe et al. $6601(\mathrm{P})-2$ & GQ256317 & GQ256395 & GQ256245 & & GQ256159 & \\
\hline \begin{tabular}{|l} 
Microsorum spectrum (Kaulf.) Copel. \\
Men
\end{tabular} & Hawaiian Islands; Wood 10936 (LOA) & EU482967 & EU483018 & EU483064 & - & 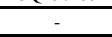 & - \\
\hline \begin{tabular}{|l} 
Microsorum spectrum (Kaulf.) Copel. \\
\end{tabular} & Hawaiian Islands; Hoshizaki 1350 (UC) & EU482968 & EU483019 & EU483065 & & & \\
\hline Microsorum steerei (Harr.) Ching & Taiwan Islands; CC.Chen $1013(\mathrm{H})$ & MH051183 & MH113482 & MH113515 & MH113548 & MH113582 & MH113615 \\
\hline
\end{tabular}




\begin{tabular}{|c|c|c|c|c|c|c|c|}
\hline Microsorum thailandicum T. Booknerd \& Noot. & cult. BGG; Schwertfeger s.n. (GOET) & EU482969 & EU483020 & EU483066 & - & - & - \\
\hline \begin{tabular}{|l} 
Microsorum vieillardii (Mett.) Copel. \\
\end{tabular} & cult. CAG; Smith s.n. (UC) & DQ179634 & DQ179637 & DQ179644 & - & - & \\
\hline \begin{tabular}{|l} 
Microsorum vieillardii (Mett.) Copel. \\
\end{tabular} & cult. DBG; Schneider s.n. (GOET) & DQ179635 & DQ179638 & DQ179645 & - & & \\
\hline Microsorum whiteheadii A.R.Sm. \& Hoshiz. & Sumatra Island; Whitehead s.n. (UC) & EU482970 & EU483021 & EU483067 & - & - & - \\
\hline Neocheiropteris palmatopedata (Baker) Christ & Mainland China: Yunnan province; Zhang $4482(\mathrm{PE})$ & GQ256318 & GQ256396 & GQ256246 & - & GQ256160 & - \\
\hline Neocheiropteris palmatopedata (Baker) Christ & cult. KBG; Kim 2012-1 (KUN) & JX103706 & JX103748 & $\begin{array}{l}\text { JX103790 } \\
\end{array}$ & - & JX103664 & - \\
\hline \multirow{3}{*}{ Neocheiropteris palmatopedata (Baker) Christ } & Mainland China; Schneider s.n. (BGUZ) (GOET) & AY362567 & AY362640 & & - & - & - \\
\hline & cult. BGG, Schneider s.n. (GOET) & - & - & DQ212059 & - & - & - \\
\hline & cult.; Schneider s.n. (GOET) & - & - & & EF463833 & EF463502 & - \\
\hline Neocheiropteris palmatopedata (Baker) Christ & Mainland China: Sichuan province; Kuo 1552 (TAIF) & MH051185 & MH113484 & MH113517 & MH113550 & MH113584 & MH113617 \\
\hline Neocheiropteris triglossa (Baker) Ching & Mainland China: Yunnan province; W.M. Zhu 57112 (KUN) & HQ597010 & & HQ597019 & & HQ597024 & - \\
\hline Neolepisorus ensatus (Thunb.) Ching & Korean Peninsula; Zhang 3611 (PE) & GQ256319 & GQ256397 & GQ256247 & & GQ256161 & \\
\hline \begin{tabular}{|l|l} 
Neolepisorus ensatus (Thunb.) Ching \\
\end{tabular} & Taiwan Islands; CC.Chen 1011 (H) & MH051184 & MH113483 & MH113516 & MH113549 & MH113583 & MH113616 \\
\hline Neolepisorus fortunei (T.Moore) Li Wang & Mainland China: Yunnan province; Shui $80768(\mathrm{PE})$ & & GQ256393 & GQ256243 & - & GQ256157 & - \\
\hline Neolepisorus fortunei (T.Moore) Li Wang & cult. KBG, China; Kim 2012-5 (KUN) & JX103702 & JX103744 & JX103786 & - & JX103660 & - \\
\hline \multirow{2}{*}{ Neolepisorus fortunei (T.Moore) Li Wang } & Taiwan Islands; Ranker 2087 (COLO) & DQ642159 & DQ642197 & DQ642242 & - & - & - \\
\hline & Taiwan Islands; E. Schuettpelz 1074A (DUKE) & - & - & te & - & - & KF909024 \\
\hline Neolepisorus fortunei (T.Moore) Li Wang & Mainland China; Zhang 3446 (PE) & EU482955 & EU483006 & EU483052 & - & - & - \\
\hline Neolepisorus fortunei (T.Moore) Li Wang & Taiwan Islands; CC.Chen 1012 (H) & MH051186 & MH113485 & MH113518 & MH113551 & MH113585 & MH113618 \\
\hline Neolepisorus fortunei (T.Moore) Li Wang & Taiwan Islands; CC.Chen 1096 (H) & - & MH665154 & MH665218 & - & - & - \\
\hline \multirow[b]{2}{*}{ Neolepisorus ovatus (Wall. ex Bedd.) Ching } & Mainland China; Zhang 728-1 (PE) & EU482972 & EU483023 & EU483068 & - & - & - \\
\hline & Mainland China: Yunnan province, Yongren; X.Y.Du 0936 (KUN) & & & & & HQ597028 & - \\
\hline \begin{tabular}{|l} 
Neolepisorus ovatus (Wall. ex Bedd.) Ching \\
\end{tabular} & Mainland China: Hubei province; CC.Chen $1041(\mathrm{H})$ & MH051187 & MH113486 & MH113519 & MH113552 & MH113586 & MH113619 \\
\hline \multirow{2}{*}{ Neolepisorus ovatus (Wall. ex Bedd.) Ching } & Mainland China: Sichuan province; Kuo 2171 (TAIF) & MH665088 & MH665155 & MH665219 & - & - & - \\
\hline & Mainland China: Yunnan province; Shui YM et al. 80898 & & & & - & KX891395 & - \\
\hline Neolepisorus phyllomanes (Christ) Ching & cult. RBGE; Nicholson s.n. (E) & EU482973 & EU483024 & EU483069 & - & - & - \\
\hline Neolepisorus zippelii (Blume) L. Wang & Indonesia Islands: Java; Tsutsumi IN112 (TI) & $\mathrm{AB} 232411$ & DQ642203 & DQ642249 & - & - & - \\
\hline Neolepisorus zippelii (Blume) L. Wang & Indonesia Islands: Java; Wade 1794 (TAIF) & MH051188 & MH113487 & MH113520 & MH113553 & MH175523 & MH113620 \\
\hline Neolepisorus $s p$. & Mainland China: Chongqing; Wei R WR147 (PE) & KX891380 & KX891399 & KX891367 & - & KX891396 & - \\
\hline \multirow{2}{*}{ Paragramma longifolia (Blume) T. Moore } & Malay Peninsula; Cranfill BF012 (UC) & DQ642157 & DQ642195 & DQ642239 & - & - & - \\
\hline & cult. BGM; Schneider s.n. (GOET) & 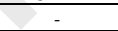 & - & & EF463825 & EF463497 & - \\
\hline Platygyria $x$ inaequibasis Ching \& S.K. Wu & Tibetan Plateau; Zhang $4615(\mathrm{PE})$ & GQ256320 & GQ256398 & GQ256248 & - & GQ256162 & - \\
\hline Platygyria soulieana (Christ) X.C. Zhang \& Q.R. Liu & Mainland China: Sichuan province; Zhang 5168 (PE) & GQ256321 & GQ256399 & GQ256249 & - & GQ256163 & - \\
\hline Platygyria waltonii (Ching) Ching and S.K. Wu & Tibetan Plateau; Zhang 4639 (PE) & GQ256322 & GQ256400 & GQ256250 & - & GQ256164 & - \\
\hline Platygyria waltonii (Ching) Ching and S.K. Wu & Mainland China; Cranfill 94-266-29 (UC) & EU482944 & EU482994 & $\mathrm{U} 483039$ & - & & - \\
\hline Thylacopteris papillosa (Blume) J.Sm. & Indonesia Islands: Java; Gravendeel et al. 559 (L) & AY459175 & AY459188 & AY459183 & EF463856 & EF463518 & - \\
\hline Thylacopteris papillosa (Blume) J.Sm. & Borneo Island; Daniele Cicuzza 2258 (UBDH) & MH665089 & MH665156 & MH665220 & MH665002 & $\begin{array}{l}\text { MH665016 } \\
\end{array}$ & - \\
\hline \multirow{2}{*}{ Tricholepidium normale (D. Don) Ching } & Yunnan; Shui 80596 (PE) & GQ256323 & GQ256401 & GQ256251 & - & & - \\
\hline & cult. KBG; X.Y.Du 1004 (KUN) & - & - & - & - & HQ597025 & - \\
\hline $\begin{array}{l}\text { Tricholepidium normale (D. Don) Ching } \\
\end{array}$ & Indochina: Vietnam; Wade 2649 (TAIF) & MH175520 & MH113490 & MH113523 & MH113556 & MH113589 & MH113623 \\
\hline Tricholepidium normale (D. Don) Ching & Indochina: Vietnam; Wade 4101 (TAIF) & MH665090 & MH665157 & MH665221 & MH665003 & MH665017 & MH665027 \\
\hline \multirow{3}{*}{ Aglaomorpha meyeniana Schott } & cult. Goettingen; Janssen 2260 (GOET) & AY529153 & & 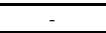 & - & - & - \\
\hline & cult. Goettingen; Janssen V-17 (GOET) & - & AY459185 & - & - & - & - \\
\hline & cult. KBCC K016952 & - & - & FJ807657 & $\mathrm{JF} 304020$ & & JF303958 \\
\hline \multirow{2}{*}{ Polypodium glycyrrhiza D.C. Eaton } & Canada: Squamish-Lillooet; Rothfels 4086 (DUKE) & KP136832* & - & KP136832* & KP136832* & KP136832* & KP136832* \\
\hline & cult. BGG; Schwerffeger s.n. (GOET) & & FJ825671 & & & & - \\
\hline \multirow{3}{*}{ Pyrrosia polydactyla (Hance) Ching } & Taiwan Islands; Ranker 2080 (COLO) & EF463259 & & & EF463844 & EF463511 & - \\
\hline & Taiwan Islands; Knapp 3801 (P) & - & KY931286 & KY931410 & $c^{-1}$ & - & - \\
\hline & TTaiwan Islands: Lu PF 21430 (PE) & & & & & & KY633008 \\
\hline
\end{tabular}


Table 2. List of primers for amplifying the gene regions used in this study.

\begin{tabular}{|c|c|c|c|c|}
\hline Gene & Primer & Direction & Sequence & Reference \\
\hline \multirow[t]{5}{*}{ rbcL } & F1 & Forward & ATGTCACCACAAACGGAGAC & Li, C., Lu, S. \& Yang, Q. (2004) \\
\hline & $\mathrm{rbcL} 341 \mathrm{~F}$ & Forward & CCTTCGAATTCCTCCCGCTT & This study \\
\hline & $\mathrm{R} 1379$ & Reverse & GCAGCTAATTCAGGACTCC & Li, C., Lu, S. \& Yang, Q. (2004) \\
\hline & rbcL1105R & Reverse & TCGGTTAGAGCAGGCATGTG & This study \\
\hline & $\mathrm{cR}$ & Reverse & GCAGCAGCTAGTTCCGGGCTCCA & Hasebe et al. (1994) \\
\hline \multirow[t]{2}{*}{ rps4+rps4-trnS } & $\mathrm{rps} 4 \mathrm{~F}$ & Forward & ATGTCSCGTTAYCGAGGACCT & Small et al. (2005) \\
\hline & $\operatorname{trnS}$ & Reverse & TACCGAGGGTTCGAATC & Schneider et al. (2005) \\
\hline \multirow[t]{3}{*}{$\operatorname{trn} L+\operatorname{trn} L-\operatorname{trn} F$} & $\operatorname{trnLfern} 1$ & Forward & GGCAGCCCCCARATTCAGGGRAACC & Trewick et al. (2002) \\
\hline & $\operatorname{trnFf}$ & Reverse & ATTTGAACTGGTGACACGAG & Taberlet et al. (1991) \\
\hline & $\operatorname{trnLd}$ & Reverse & GGGGATAGAGGGACTTGAAC & Taberlet et al. (1991) \\
\hline \multirow[t]{2}{*}{ atpB } & ESATPB172F & Forward & AATGTTACTTGTGAAGTWCAACAAT & Schuettpelz \& Pryer (2007) \\
\hline & ATPB910R & Reverse & TTCCTGYARAGANCCCATTTCTGT & Schuettpelz \& Pryer (2007) \\
\hline \multirow[t]{3}{*}{ matK } & PolypodF1 & Forward & ATTTYTGGARGAYAGAYTDCC & Proposed by the CBoL Plant Barcoding \\
\hline & PolypodF2 & Forward & AATTTCRCARTCYAYYCATTC & Working group (http://www.boldsystems. \\
\hline & PolypodR1 & Reverse & CGTRGTATATATCTCRATYTACGC & org/index.php/Public_Primer_PrimerSearch) \\
\hline
\end{tabular}


Table 3 Best-fitting models and parameter values of large and small dataset for separate genes of rbcL, rps4 \& rps4- trnS IGS, trnL-trnF region, atpA, atpB \& rbcL-atpB IGS, and matK.

\begin{tabular}{lllll|llll}
\hline \multirow{2}{*}{ DNA regions } & \multicolumn{4}{c|}{ Large dataset } & & \multicolumn{3}{c}{ Small dataset } \\
\cline { 2 - 9 } & Selected model & taxa & sites & Constant sites & Selected model & taxa & sites & Constant sites \\
\hline rbcL & BIC: TIM2e+R4 & 308 & 1237 & $66 \%$ & BIC: TIM2e+R3 & 49 & 1237 & $78 \%$ \\
rps4 + rps4- trnS & BIC: TVM+R4 & 310 & 1169 & $45 \%$ & BIC: K3Pu+G4 & 50 & 1044 & $50 \%$ \\
trnL + trnL-trnF & BIC: TVM+R4 & 302 & 1088 & $42 \%$ & BIC: K3Pu+R3 & 49 & 931 & $50 \%$ \\
atpA & BIC: TIM+I+G4 & 64 & 1023 & $72 \%$ & BIC: TIM3+G4 & 45 & 1013 & $73 \%$ \\
rbcL-atpB + atpB * & BIC: GTR+I+G4 & 185 & 1584 & $68 \%$ & BIC: TNe+R2 & 47 & 676 & $76 \%$ \\
matK & BIC: TVM+R3 & 53 & 834 & $43 \%$ & BIC: TVM+R3 & 40 & 834 & $44 \%$ \\
six-combination & BIC: GTR+R5 & 316 & 6935 & $57 \%$ & BIC: GTR+R4 & 50 & 5735 & $62 \%$ \\
four-combination & BIC: TVM+R5 & 316 & 5078 & $57 \%$ & - & - & - & - \\
three-combination & BIC: TVM+R5 & 316 & 3494 & $51 \%$ & - & - & - & - \\
\hline
\end{tabular}

* atpB \& rbcL-atpB are analysed in large dataset, and atpB was analysed in small dataset. 
Table 4 The proposed generic names, following the status of the name based on the Tropicos database (tropicos.org), type species \& if it is included in this study. Group indicates the clade that the type species of the genus belongs to; Mono indicates if the genus is monophyletic or not, and an asterisk * that only one species is included in this study; the last column shows original and lectotype publications. Names in bold used in this study. Abbreviations: leg., legitimate; nom. cons., conserved name; nom. rej., name rejected; illeg. hom., name illegitimate due to homonymy; LT, lectotype; -, lack of data.

\begin{tabular}{|c|c|c|c|c|c|c|}
\hline generic names & Status & Type species/Included & & Groups & Mono & publications \\
\hline Belvisia Mirbel & nom. rej. & $\begin{array}{l}\text { [LT] Belvisia spicata (L. f.) Mirb. ex Copel. } \\
\equiv \text { Lepisorus spicatus (L.f.) Li Wang }\end{array}$ & Yes & Lepisorus & Yes & $\begin{array}{l}\text { Hist. Nat. Vég. 3: 473; 5: 111. } 1803 . \\
\text { [LT] Gen. Fil.: 192. } 1947 .\end{array}$ \\
\hline Bosmania Testo & leg. & $\begin{array}{l}\text { Bosmania membranacea (D. Don) Testo } \\
\equiv \text { Microsorum membranaceum (D. Don) Ching }\end{array}$ & Yes & MG1 & Yes & Syst. Bot. 44: 1-16. 2019. \\
\hline Caobangia A.R.Sm. \& X.C.Zhang & leg. & $\begin{array}{l}\text { Caobangia squamata A.R.Sm. \& X.C.Zhang } \\
\equiv \text { Lemmaphyllum squamatum (A.R.Sm. \& } \\
\text { X.C.Zhang) Li Wang }\end{array}$ & Yes & Lemmaphyllum & Yes* & Novon 12: 546-549, f. 1. 2002. \\
\hline Christiopteris Copel. & leg. & $\begin{array}{l}\text { Christiopteris sagitta (Christ) Copel. } \\
\equiv \text { Aglaomorpha sagitta (Christ) Hovenkamp \& } \\
\text { S.Linds }\end{array}$ & No & - & - & Fragm. FI. Philipp.: 188. 1905. \\
\hline Colysis C. Presl & - & $\begin{array}{l}\text { [LT] Colysis hemionitidea (Wall. Ex Mett.) C. Presl } \\
\equiv \text { Leptochilus hemionitideus (C. Presl) Noot. }\end{array}$ & Yes & Leptochilus & No & $\begin{array}{l}\text { Epim. Bot.: 146. } 1849 . \\
\text { [LT] Index Filic., Suppl. 3: 12. } 1934 .\end{array}$ \\
\hline Dendroconche Copel. & leg. & $\begin{array}{l}\text { Dendroconche annabellae (H.O. Forbes) Copel. } \\
\text { = Microsorum linguiforme (Mett.) Copel. }\end{array}$ & Yes & MG3 & Yes & Philipp. J. Sci., C. 6: 91.1911. \\
\hline Dendroglossa C. Presl & - & $\begin{array}{l}\text { [LT] Dendroglossa normalis C. Presl. } \\
\equiv \text { Leptochilus minor Fée }\end{array}$ & No & - & No & $\begin{array}{l}\text { Epim. Bot.: 149. } 1849 . \\
\text { [LT] Gen. Fil.: 199. } 1947 .\end{array}$ \\
\hline Diblemma J. Smith & leg. & $\begin{array}{l}\text { Diblemma samarensis J. Sm. } \\
\equiv \text { Microsorum samarense (J. Sm.) Bosman }\end{array}$ & No & - & - & J. Bot. (Hooker). 3: 399. 1841. \\
\hline Dictymia J. Smith & leg. & Dictymia attenuata (R. Br.) J. Sm. & No & - & - & Bot. Mag. 72(Comp.): 16. 1846. \\
\hline Drymotaenium Makino & nom. rej. & $\begin{array}{l}\text { Drymotaenium miyoshianum (Makino) Makino. } \\
=\text { Lepisorus miyoshianus (Mak.) Fraser-Jenk. \& }\end{array}$ & Yes & Lepisorus & Yes* & Bot. Mag. (Tokyo). 15(174): 102. 1901. \\
\hline
\end{tabular}




\begin{tabular}{|c|c|c|c|c|c|c|}
\hline Goniophlebium (Blume) C. Presl & leg. & $\begin{array}{l}\text { [LT] Goniophlebium subauriculatum (Blume) C. } \\
\text { Presl }\end{array}$ & Yes & Goniophlebium & Yes & $\begin{array}{l}\text { Tent. Pterid.: 186. } 1836 . \\
\text { [LT] Taxon 39: 105. } 1990 .\end{array}$ \\
\hline Kaulinia B.K. Nayar & - & $\begin{array}{l}\text { Kaulinia pteropus (Blume) B.K. Nayar } \\
\text { इ Microsorum pteropus (Blume) Copel. }\end{array}$ & Yes & Leptochilus & No & Taxon 13: 67. 1964. \\
\hline Kontumia S.K.Wu \& K.L.Phan & - & $\begin{array}{l}\text { Kontumia heterophylla S.K. Wu \& K.L. Phan } \\
=\text { Leptochilus heterophylla (S.K. Wu \& K.L. Phan) } \\
\text { Christenh. }\end{array}$ & Yes & Leptochilus & Yes* & Novon 15(1): 245-247, f. 1, 2. 2005. \\
\hline Lecanopteris Reinw. & leg. & Lecanopteris carnosa (Reinw.) Blume & Yes & Lecanopteris & Yes & Flora 8(2, Beil.): 48. 1825. \\
\hline Lemmaphyllum C.PresI & leg. & $\begin{array}{l}\text { [LT] Lemmaphyllum spatulatum C. Presl } \\
=\text { Lemmaphyllum carnosum (Hook.) C. Presl }\end{array}$ & Yes & Lemmaphyllum & Yes & $\begin{array}{l}\text { Epim. Bot.: 157. } 1849 . \\
\text { [LT] Gen. Fil.: 189. } 1947 .\end{array}$ \\
\hline Lepidogrammitis Ching & - & $\begin{array}{l}\text { Lepidogrammitis drymoglossoides (Baker) Ching } \\
=\text { Lemmaphyllum drymoglossoides (Baker) Ching }\end{array}$ & Yes & Lemmaphyllum & No & Sunyatsenia 5(4): 258. 1940. \\
\hline $\begin{array}{l}\text { Lepidomicrosorium Ching \& } \\
\text { K.H.Shing }\end{array}$ & leg. & $\begin{array}{l}\text { Lepidomicrosorium subhastatum (Baker) Ching } \\
=\text { Lepidomicrosorium buergerianum (Miq.) Ching \& } \\
\text { K.H. Shing }\end{array}$ & Yes & Lepidomicrosorium & Yes & Bot. Res. Academia Sinica. 1:1. 1983. \\
\hline Lepisorus (J.Sm.) Ching & $\begin{array}{l}\text { nom. } \\
\text { cons. }\end{array}$ & Lepisorus nudus (Hook.) Ching & No & - & Yes & Bull. Fan Mem. Inst. Biol. 4: 47. 1933. \\
\hline Leptochilus Kaulf. & leg. & Leptochilus axillaris (Cav.) Kaulf. & Yes & Leptochilus & Yes & Enum. Filic. 147, pl. 1, f. 10. 1824. \\
\hline Metapolypodium Ching & leg. & $\begin{array}{l}\text { Metapolypodium manmeiense (Christ) Ching } \\
\text { 三 Goniophlebium manmeiense (Christ) Rödl-Linder }\end{array}$ & Yes & Goniophlebium & Yes & Acta Phytotax. Sin. 16(4): 28. 1978. \\
\hline Microsorum Link & leg. & $\begin{array}{l}\text { Microsorum irregulare Link } \\
=\text { Microsorum punctatum (L.) Copel. }\end{array}$ & Yes & core Microsorum & No & Hort. Berol. 2: 110. 1833. \\
\hline Myrmecophila (H.Christ) ex Nakai & illeg. hom. & $\begin{array}{l}\text { Myrmecophila sinuosa (Hook.) Nakai ex H. Itô. } \\
\equiv \text { Lecanoperis sinuosa (Hook.) Copel. }\end{array}$ & Yes & Lecanopteris & Yes* & Bot. Mag. (Tokyo). 43: 6. 1929. \\
\hline Myrmecopteris Pichi Serm. & - & $\begin{array}{l}\text { Myrmecopteris sinuosa (Wall. ex Hook.) Pic. Serm. } \\
\equiv \text { Lecanopteris sinuosa (Wall. ex Hook.) Copel. }\end{array}$ & Yes & Lecanopteris & No & Webbia 31: 239. 1977. \\
\hline
\end{tabular}


Myuropteris C. Chr.

\section{Neocheiropteris H. Christ \\ Neolepisorus Ching \\ Nistarika B.K. Nayar, Madhus. \& Molly \\ Paragramma (Blume) T.Moore}

Paraleptochilus Copel.

Phymatosorus Pic.Serm.

Platygyria Ching \& S.K.Wu

Podosorus Holttum

Polypodiastrum Ching

Polypodiodes Ching

Schellolepis J.Sm.

Thylacopteris Kunze ex J. Smith Tricholepidium Ching

Weatherbya Copel.

Zealandia Testo \& A. R. Field
Myuropteris cordata (Christ) C. Chr.

= Leptochilus cantoniensis (Baker) Ching

leg. Neocheiropteris palmatopedata (Baker) Christ

leg. Neolepisorus ensatus (Thunb.) Ching

nom. rej. [LT] Paragramma longifolia (Blume) T. Moore

$-$

leg.

Paraleptochilus decurrens (Blume) Copel.

$\equiv$ Leptochilus decurrens Blume

Phymatosorus scolopendria Pichi Serm.

ミMicrosorum scolopendria (Burm. f.) Copel.

Platygyria waltonii (Ching) Ching \& S.K. Wu.

三Lepisorus waltonii (Ching) S.L.Yu

Podosorus angustatus Holttum

leg. Polypodiastrum argutum (Wall. ex Hook.) Ching.

ミ Goniophlebium argutum (Wall. ex Hook.) J. Sm.

leg.

Polypodiodes amoena (Wall. ex Mett.) Ching

三 Goniophlebium amoenum (Wall. ex Mett.) Bedd.

[LT] Schellolepis verrucosa (Wall. ex Hook.) J. Sm.

= Goniophlebium percussum (Cav.) Wanger \&

Grether

Thylacopteris papillosa (Blume) J. Sm.

leg. Tricholepidium normale (D. Don) Ching

- Weatherbya accedens (Blume) Copel.

= Lepisorus accedens (Blume) Hosok.

leg. Zealandia pustulata (G. Forst.) Testo\&A. R. Field

इMicrosorum pustulatum (G. Forst.) Copel.

Yes

Leptochilus

Dansk Bot. Ark. 6(3): 73. 1929

Yes

Yes

Yes

Yes

Yes

Leptochilus

Yes

Lepisorus

No -

Yes

Goniophlebium

No

Neocheiropteris

Neolepisorus

Leptochilus

Paragramma

Thylacopteris

Tricholepidium

Lepisorus

MG2
Goniophlebium Yes

Yes

Yes
Bull. Soc. Bot. France: Mem. 1: 21. 1905.

Bull. Fan Mem. Inst. Biol., Bot. 10(1): 11-12. 1940.

Fern Gaz. 13(1): 33, f. 1-6. 1985

Index Fil. xxxii. 1857.

[LT] Hist. Fil.: 114. 1875

Gen. Fil. 198, t. 7. 1947

Webbia 28: 457. 1973.

Acta Bot. Yunnan. 2(1): 67-68. 1980

Kew Bull. 20: 455. 1966.

Acta Phytotax. Sin. 16(4): 27-28. 1978.

Acta Phytotax. Sin. 16(4): 26-27. 1978.

Ferns Brit. For.: 82. 1866

[LT] Hist. Fil.: 93. 1875.

Yes* Hist. Fil. 87. 1875.

Yes* $\quad$ Acta Phytotax. Geobot. 29(1-5): 41. 1978.

Yes* $\quad$ Gen. Fil. 191. 1947 
Table 5 List of generic name and grouping of the microsoroid ferns in selected taxonomic and phylogenetic works. Abbreviations: GO, goniophlebioid clade; LC, lecanopteroid clade; LP, lepisoroid clade; ME, membranaceoid clade; MI, microsoroid s.s. clade; TH, thylacopteroid clade; Sf.LO, Subfamily Loxogrammoideae; Sf.DN, Subfamily Drynarioideae; Sf.MI, Subfamily Microsoroideae; T.PO, Tribe Polypodieae; T.LP, Tribe Lepisoreae; T.MI, Tribe Microsoreae; T.GO, Goniophlebieae; T.TH, Thylacoptereae; T.LC, Lecanoptereae.

\begin{tabular}{|c|c|c|c|c|c|c|c|}
\hline \multicolumn{2}{|c|}{$\begin{array}{l}\text { The previously proposed } \\
\text { generic names and grouped in } \\
\text { this study }\end{array}$} & \multicolumn{2}{|l|}{$\begin{array}{l}\text { Hennipman et al. } \\
\qquad(1990)\end{array}$} & \multicolumn{2}{|c|}{$\begin{array}{l}\text { Kreier et al. } \\
\qquad(2008)\end{array}$} & \multicolumn{2}{|c|}{$\begin{array}{c}\text { PPGI } \\
\text { (2016) }\end{array}$} \\
\hline Goniophlebium & T.GO & \multirow{4}{*}{$\begin{array}{l}\text { Polypodium- } \\
\text { Goniophlebium Group }\end{array}$} & \multirow{4}{*}{ T.PO } & Goniophlebium & GO & Goniophlebium & Sf.MI \\
\hline Metapolypodium & T.GO & & & Goniophlebium & GO & Goniophlebium & Sf.MI \\
\hline Polypodiastrum & T.GO & & & Goniophlebium & GO & Goniophlebium & Sf.MI \\
\hline Polypodiodes & T.GO & & & Goniophlebium & GO & Goniophlebium & Sf.MI \\
\hline Schellolepis & T.GO & $\begin{array}{l}\text { Polypodium- } \\
\text { Goniophlebium Group }\end{array}$ & T.PO & Goniophlebium & GO & & \\
\hline Thylacopteris & T.TH & Thylacopteris & T.PO & Thylacopteris & $\mathrm{TH}$ & Thylacopteris & Sf.MI \\
\hline Lepisorus & T.LP & Lepisorus & T.LP & Lepisorus & LP & Lepisorus & Sf.MI \\
\hline Paragramma & T.LP & Lepisorus & T.LP & Lepisorus & LP & Paragramma & Sf.MI \\
\hline Belvisia & T.LP & Belvisia & T.LP & Belvisia & LP & Lepisorus & Sf.MI \\
\hline Drymotaenium & T.LP & Drymotaenium & T.LP & Drymotaenium & LP & Lepisorus & Sf.MI \\
\hline Lemmaphyllum & T.LP & Lemmaphyllum & T.LP & Lemmaphyllum & LP & Lemmaphyllum & Sf.MI \\
\hline Caobangia & T.LP & & & & & Lemmaphyllum & Sf.MI \\
\hline Lepidogrammitis & T.LP & Lemmaphyllum & T.LP & Lepidogrammitis & LP & Lemmaphyllum & Sf.MI \\
\hline Weatherbya & T.LP & Lemmaphyllum & T.LP & Lemmaphyllum & LP & Lemmaphyllum & Sf.MI \\
\hline Lecanopteris & T.LC & Lecanopteris & T.MI & Lecanopteris & LC & Lecanopteris & Sf.MI \\
\hline Myrmecophila & T.LC & Lecanopteris & T.MI & Lecanopteris & LC & & \\
\hline
\end{tabular}




\begin{tabular}{|c|c|c|c|c|c|c|c|}
\hline Myrmecopteris & T.LC & Lecanopteris & T.MI & & & & \\
\hline Colysis & T.MI & Colysis & T.MI & Leptochilus & $\mathrm{MI}$ & Leptochilus & Sf.MI \\
\hline Dendroglossa & T.MI & Colysis & T.MI & & & & \\
\hline Myuropteris & T.MI & Colysis & T.MI & & & & \\
\hline Paraleptochilus & T.MI & Colysis & T.MI & Leptochilus & $\mathrm{Ml}$ & & \\
\hline Leptochilus & T.MI & Leptochilus & T.MI & Leptochilus & $\mathrm{MI}$ & Leptochilus & Sf.MI \\
\hline Kontumia & T.MI & & & & & Leptochilus & Sf.MI \\
\hline Nistarika & T.MI & Leptochilus & T.MI & & & & \\
\hline Microsorum & T.MI & Microsorum & T.MI & Microsorum & MI, ME, LC & Microsorum & Sf.MI \\
\hline Diblemma & T.MI & Microsorum & T.MI & & & & \\
\hline Dendroconche & T.MI & Microsorum & T.MI & Microsorum & LC & Microsorum & Sf.MI \\
\hline Kaulinia & T.MI & Microsorum & T.MI & 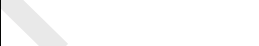 & & Microsorum & Sf.MI \\
\hline Podosorus & T.MI & Microsorum & T.MI & & & & \\
\hline Neocheiropteris & T.LP & Neocheiropteris & T.MI & Neocheiropteris & LP & Neocheiropteris & Sf.MI \\
\hline Neolepisorus & T.LP & Neocheiropteris & T.MI & Neolepisorus & LP & Neolepisorus & Sf.MI \\
\hline Tricholepidium & T.LP & Neocheiropteris & T.MI & Tricholepidium & LP & Tricholepidium & Sf.MI \\
\hline Lepidomicrosorium & T.LP & 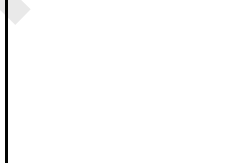 & & $\begin{array}{l}\text { Microsorum } \\
\text { Neocheiropteris } \\
\text { Lepidomicrosorum }\end{array}$ & LP & Lepidomicrosorium & Sf.MI \\
\hline Phymatosorus & T.MI & Phymatosorus & T.MI & Phymatosorus & $\mathrm{MI}$ & Microsorum & Sf.MI \\
\hline Platygyria & T.LP & Neocheiropteris & T.MI & Lepisorus & LP & & \\
\hline Dictymia & - & Dictymia & T.MI & & & Dictymia & Sf.LO \\
\hline Christiopteris & - & Christiopteris & T.MI & & & Aglaomorpha & Sf.DN \\
\hline
\end{tabular}




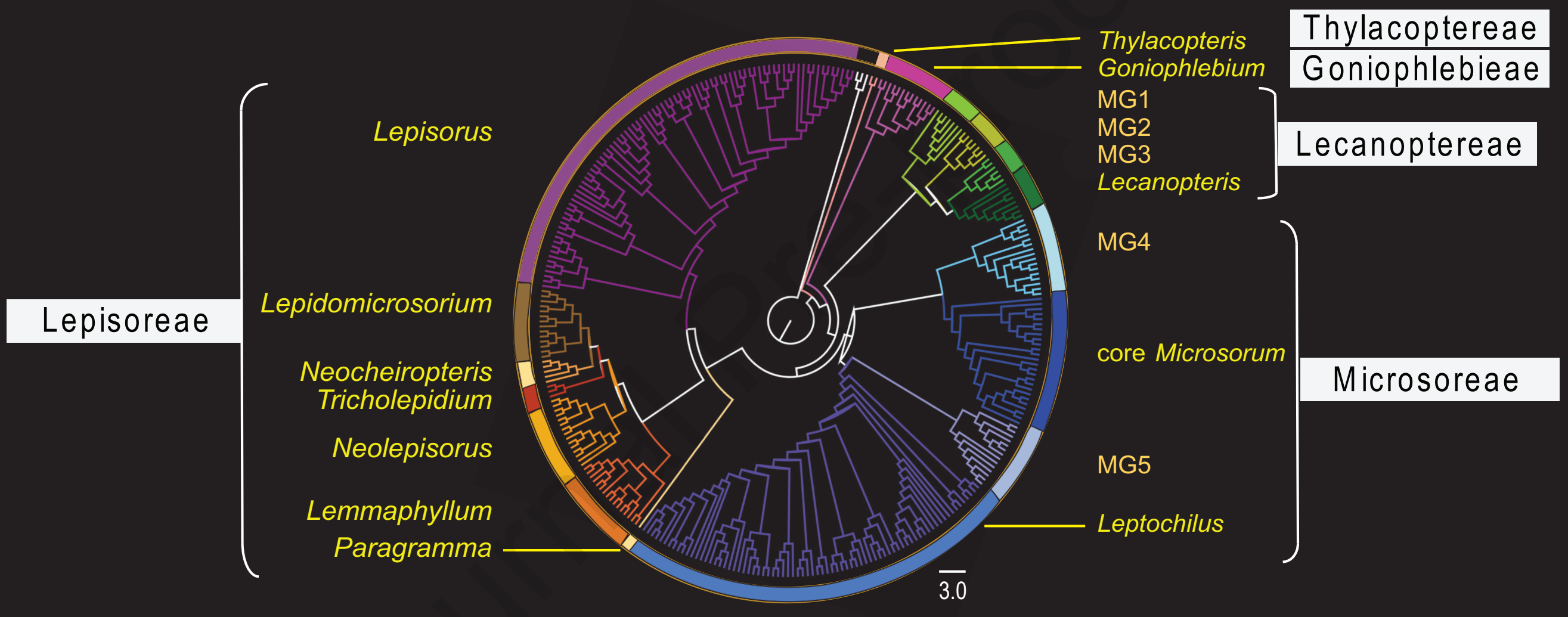




\section{Highlights}

- The microsoroid ferns comprise up to 17 genera.

- Five tribes have been identified.

- A large sampling (over 70\% species) and up to six chloroplast DNA regions have been used.

- The DNA regions matK and atpA are useful to improve the phylogenetic hypotheses of the microsoroid ferns. 